\title{
An overview of mammalian p38 mitogen-activated protein kinases, central regulators of cell stress and receptor signaling [version 1; peer review: 2 approved]
}

Jiahuai Han ${ }^{1}$, Jianfeng Wư1, John Silke (iD) 2,3

${ }^{1}$ State Key Laboratory of Cellular Stress Biology, Innovation Center for Cell Biology, School of Life Sciences, Xiamen University, Xiamen, Fujian, 361102, China

${ }^{2}$ The Walter and Eliza Hall Institute, 1G Royal Parade, Parkville, Victoria, 3052, Australia

${ }^{3}$ Department of Medical Biology, University of Melbourne, Parkville, Victoria, 3050, Australia

V1 First published: 29 Jun 2020, 9(F1000 Faculty Rev):653

https://doi.org/10.12688/f1000research.22092.1

Latest published: 29 Jun 2020, 9(F1000 Faculty Rev):653

https://doi.org/10.12688/f1000research.22092.1

\section{Abstract}

The p38 family is a highly evolutionarily conserved group of mitogenactivated protein kinases (MAPKs) that is involved in and helps coordinate cellular responses to nearly all stressful stimuli. This review provides a succinct summary of multiple aspects of the biology, role, and substrates of the mammalian family of p38 kinases. Since p38 activity is implicated in inflammatory and other diseases, we also discuss the clinical implications and pharmaceutical approaches to inhibit p38.

Keywords

p38, MAPK, inflammation, signalling

\section{Open Peer Review \\ Approval Status \\ 1 \\ 2 \\ version 1 \\ 29 Jun 2020 \\ Faculty Reviews are review articles written by the prestigious Members of Faculty Opinions. The articles are commissioned and peer reviewed before publication to ensure that the final, published version is comprehensive and accessible. The reviewers who approved the final version are listed with their names and affiliations.}

1. Jonathan D. Ashwell, National Cancer Institute, National Institutes of Health, Bethesda, USA

2. Guadalupe Sabio, Centro Nacional de Investigaciones Cardiovasculares (CNIC), Madrid, Spain

Any comments on the article can be found at the end of the article. 
Corresponding authors: Jiahuai Han (jiahuaihan@xmu.edu.cn), John Silke (silke@wehi.edu.au)

Author roles: Han J: Writing - Original Draft Preparation, Writing - Review \& Editing; Wu J: Writing - Original Draft Preparation; Silke J: Writing - Original Draft Preparation, Writing - Review \& Editing

Competing interests: No competing interests were disclosed.

Grant information: This work was supported by the National Natural Science Foundation of China (81788101, 31420103910 and 81630042 to J.H.), the 111 Project (B12001 to J.H.) and by an NHMRC fellowship (1107149) to JS.

The funders had no role in study design, data collection and analysis, decision to publish, or preparation of the manuscript.

Copyright: ( $) 2020$ Han J et al. This is an open access article distributed under the terms of the Creative Commons Attribution License, which permits unrestricted use, distribution, and reproduction in any medium, provided the original work is properly cited.

How to cite this article: Han J, Wu J and Silke J. An overview of mammalian p38 mitogen-activated protein kinases, central regulators of cell stress and receptor signaling [version 1; peer review: 2 approved] F1000Research 2020, 9(F1000 Faculty Rev):653 https://doi.org/10.12688/f1000research.22092.1

First published: 29 Jun 2020, 9(F1000 Faculty Rev):653 https://doi.org/10.12688/f1000research.22092.1 


\section{p38 mitogen-activated protein kinases}

p38 $\alpha$ (originally named p38) was identified and cloned as a $38 \mathrm{kDa}$ protein that was tyrosine-phosphorylated in response to LPS stimulation in mammalian cells ${ }^{1,2}$. Sequence comparison, on the day $\mathrm{p} 38 \alpha$ was cloned, revealed that it belonged to the mitogen-activated protein kinase (MAPK) family and that a Saccharomyces cerevisiae osmotic response protein kinase HOG1 was a p38 $\alpha$ homologue h $^{3-5} \cdot \mathrm{p} 38 \alpha$ was also named cytokine suppressive drug binding protein (CSBP) because it was identified as the target of a series of anti-inflammatory pyridinyl-imidazole compounds and as reactivating kinase (RK) because it phosphorylated and activated $\mathrm{MK} 2^{3-5}$. There are four members of the $\mathrm{p} 38$ group of MAPKs encoded by four different genes in mammals: p38 $\alpha$ (MAPK14, chromosome $6 \mathrm{p} 21.31$ in humans), p38 $\beta$ (MAPK11, SAPK2b, Chr22q13.33) ${ }^{6}$, p38y (MAPK12, ERK6, SAPK3, Chr22q13.33) 7,8 , and $\mathrm{p} 38 \delta$ $(M A P K 13, \text { SAPK4, Serk4, Chr6p21.31 })^{9,10}$. As can be surmised from their chromosomal locations, MAPK14/p38 $\alpha$ and MAPK13/ p38 $\delta$ are physically close and separated by just over $15 \mathrm{~kb}$, as are $M A P K 12 / \mathrm{p} 38 \beta$ and $M A P K 11 / \mathrm{p} 38 \gamma$, which are separated by less than $2 \mathrm{~kb}$. All the p38s contain a conserved Thr-GlyTyr (TGY) dual phosphorylation motif within the kinase activation loop, and both $\mathrm{Thr}$ and $\mathrm{Tyr}$ phosphorylation are necessary to fully activate the kinase ${ }^{11}$. However, monophosphorylated $\mathrm{p} 38 \alpha \mathrm{Thr}^{180}$ has some kinase activity in vitro, but a different substrate specificity, when compared with dual-site phosphorylated p38 $\alpha^{12}$. p38 group members are expressed ubiquitously, but $\mathrm{p} 38 \gamma$ and $\mathrm{p} 38 \delta$ are enriched in certain cell types and tissues, such as p38 $\gamma$ in skeletal muscle and $\mathrm{p} 38 \delta$ in the salivary, pituitary, and adrenal glands ${ }^{13}$. p38 $\beta$ shares more amino acid sequence identity with p38 $\alpha(\sim 70 \%)$, while p38 $\gamma$ and p38 $\delta$ share $\sim 60 \%$ identity with $\mathrm{p} 38 \alpha$. p38 $\gamma$ and $\mathrm{p} 38 \delta$ also share high sequence homology with cyclin-dependent kinases (CDKs) and are sensitive to some CDK inhibitors ${ }^{14}$.

\section{Activation and inactivation of p38}

p38 $\alpha$ is involved in the response to almost all stressful stimuli, including LPS, UV light, heat shock, osmotic shock, inflammatory cytokines, $\mathrm{T}$ cell receptor ligation, glucose starvation, and oncogene activation ${ }^{2,4,5,15-20}$. Under certain circumstances, it is also activated upon growth factor stimulation. It should be noted that the activation of p38 in some cases is cell type specific, since an activating stimulus in one cell type may inhibit p38 in other cell types ${ }^{21}$. The study of p38 group members other than $\mathrm{p} 38 \alpha$ has been less intensive; however, where it has been examined, the other $\mathrm{p} 38 \mathrm{~s}$ are frequently co-activated with $\mathrm{p} 38 \alpha^{22}$

Like other MAPK signaling pathways, the activation of all p38s is mediated by a kinase cascade: MAPKKK (MAP3K), which activates MAPKK (MAP2K), which in turn activates MAPK. The MAP2K kinases MKK3 and MKK6 are the major upstream kinases for p38 activation ${ }^{23-25}$. Although MKK3 and MKK6 phosphorylate most p38 isoforms in vitro, selective activation and substrate specificity have been observed in vivo ${ }^{26}$. MKK4 has also been reported to phosphorylate $\mathrm{p} 38 \alpha$ and $\mathrm{p} 38 \delta$ in specific cell types ${ }^{9}$. A number of MAP3Ks have been reported to participate in $\mathrm{p} 38$ activation including $\mathrm{TAK} 1^{27}, \mathrm{ASK} 1^{28}$, $\mathrm{DLK}^{29}$, and MEKK4 ${ }^{29,30}$. Low-molecular-weight GTP-binding proteins in the Rho family, such as Rac1 and Cdc42, can activate p38 through binding to MEK1 or MLK1, which function as upstream activators of MAP3 $\mathrm{K}^{31,32}$.

p38 $\alpha$ can also be activated by MAP2K-independent mechanisms. TAB1 (TAK1-binding protein 1) directly interacts with p38 $\alpha$ and can promote trans autophosphorylation on $\mathrm{Thr}^{180}$ and $\mathrm{Tyr}^{182}$ and thus full activation of $\mathrm{p} 38 \alpha^{33}$. A subsequent study revealed that autophosphorylation of $\mathrm{Thr}^{180}$ and $\mathrm{Tyr}^{182}$ requires a conserved $\mathrm{Thr}^{185}$ residue $^{34}$. TAB1-dependent $\mathrm{p} 38 \alpha$ activation has been implicated in ischemic myocardial injury and T cell anergy ${ }^{35,36}$. TAB 1 is also claimed to play a role in Sestrin-mediated p38 $\alpha$ activation $^{12}$. Another MAP2K-independent activation is mediated by ZAP70 after $\mathrm{T}$ cell receptor ligation. ZAP70 can directly phosphorylate $\mathrm{p} 38 \alpha / \beta$ on $\mathrm{Tyr}^{32318}$, leading to autophosphorylation on $\mathrm{Thr}^{180}$, one of the dual phosphorylation sites. As discussed, mono-Thr ${ }^{180}$ phosphorylated p38 still has some kinase activity $^{37}$, and loss of ZAP70-mediated p38 activation in $\mathrm{p} 38 \alpha \beta^{\mathrm{Y} 323 \mathrm{~F}}$ double knock-in mice reduces autoimmunity and inflammation in several autoimmune disease models ${ }^{38-40}$. Interestingly, p38 $\alpha$ also phosphorylates ZAP70, resulting in a decrease in the size and persistence of the $\mathrm{T}$ cell receptor signaling complex, and therefore acts as a feedback regulator of ZAP70 ${ }^{41}$.

Conversely, de-phosphorylation of both threonine and tyrosine residues in the activation loop inactivates MAPKs, and this is mainly carried out by dual-specificity phosphatases of the MAPK phosphatase (MKP)/dual specificity phosphatase (DUSP) family ${ }^{42}$. Although several MKPs have been reported to dephosphorylate $\mathrm{p} 38 \alpha, \quad$ MKP1/DUSP1, MKP5/DUSP10, MKP8/DUSP26, and DUSP8 are more potent inhibitors of $\mathrm{p} 38 \alpha$ and JNK than $\mathrm{ERK}^{43}$. A recent report showed that DUSP12 is also a $\mathrm{p} 38 \alpha$ phosphatase ${ }^{44}$. While there are a number of $\mathrm{p} 38 \alpha$ DUSPs, no DUSP for $\mathrm{p} 38 \gamma$ or $\mathrm{p} 38 \delta$ has been reported, and these two p38s are resistant to several known p38 $\alpha$ MKPs such as MKP1, 3, 5, and $7^{45}$. p38 $\alpha$-dependent upregulation of MKP1 was reported and is believed to be part of a negative feedback loop of p38 $\alpha$ activation $^{46}$. Other types of phosphatases have also been reported to target p38 MAPKs, such as CacyBP/SIP ${ }^{47}$, Wip $1^{48}$, and $\mathrm{PP} 2 \mathrm{C}^{49,50}$. The substrate specificity between $\mathrm{p} 38$ and phosphatases and the related physiological functions in vivo still need further investigation. $\mathrm{p} 38 \gamma$ has also been reported to be degraded by a p38/JNK/ubiquitin-proteasome-dependent pathway, which represents an additional mechanism by which p38 kinases may cross regulate each other ${ }^{51}$. Yet other ways of regulating p38 are suggested from studies in Caenorhabditis elegans, where a genetic screen for resistance against bacterial infection identified RIOK-1, an atypical serine kinase and human RIO kinase homolog, as a suppressor of the p38 pathway $^{52}$. As RIOK-1 is a transcriptional target of the p38 pathway in C. elegans, this suggests that RIOK-1 is part of a negative feedback loop. A brief summary of the p38 pathway is shown in Figure 1. 


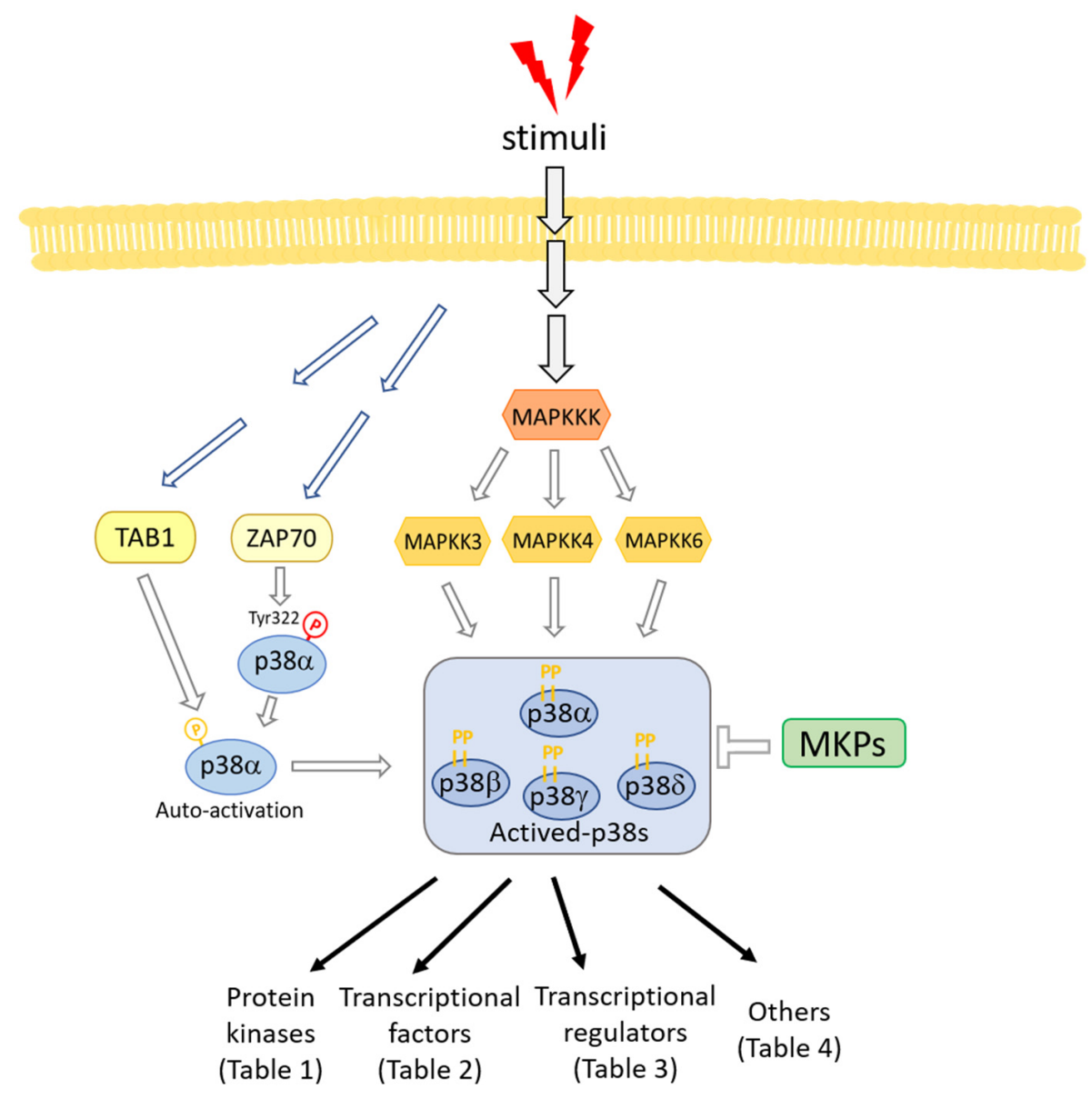

Figure 1. A diagram of the $\mathbf{p} 38$ pathway. MKP, mitogen-activated protein kinase phosphatase; TAB1, TAK1-binding protein 1; Tyr, tyrosine.

\section{Downstream substrates of $\mathrm{p} 38$ \\ Protein kinases}

The p38 MAPK cascade does not end at p38. Members of the MAPK-activated protein kinase (MAPKAPK) family such as MK2, MK3, and MK5 (PRAK) are all p38 substrates ${ }^{3,4,53-55}$. The MKs have a broad range of substrates that extend the range of functions regulated by p38 kinases. Mitogen- and stressactivated protein kinase-1/2 (MSK1/2), which are important for CREB activation and chromosome remodeling, have also been identified as substrates of $\mathrm{p} 38 \alpha^{56}$. MNK1/2, kinases that phosphorylate the eukaryotic initiation factor-4e (eIF-4E), are phosphorylated by $\mathrm{p} 38 \alpha^{57,58}$. p $38 \alpha$ has also been reported to inactivate murine GSK3 $\beta$ by phosphorylating $\operatorname{Ser}^{389}$, and since GSK3 $\beta$ is required for the continuous degradation of $\beta$-catenin in the Wnt signaling pathway, this can lead to an accumulation of $\beta$-catenin ${ }^{59,60}$. It was also reported that $\mathrm{p} 38 \delta$ negatively regulates insulin secretion by catalyzing an inhibitory phosphorylation of PKD $1^{61}$. A number of p38 protein kinase substrates are summarized in Table 1.

\section{Transcription factors}

p38 targets a large number of transcription factors, including myocyte-specific enhancer factor 2 (MEF2) family members, cyclic AMP-dependent transcription factor 1, 2, and 6 (ATF-1/2/6), CHOP (growth arrest and DNA damage inducible gene 153, or GADD153), p53, C/EBP $\beta$, MITF1, DDIT3, ELK1/4, NFAT, and STAT1/4. p38 phosphorylation of transcription factors predominantly leads to enhanced transcriptional activity. However, in some cases, it represses transcription, and this is summarized in Table 2. Transcription factor phosphorylation by p38 is often stimulus and cell type dependent and plays a role in the cellular response to inflammation, DNA damage, metabolic stress, and many other stresses ${ }^{62-76}$. The effects of p38 on transcription seem to constitute the major part of p38's responses to stress stimuli.

Transcriptional regulators

A large number of transcriptional regulators, including epigenetic enzymes, are substrates of p38, and these are summarized 


\begin{tabular}{|c|c|c|c|}
\hline Substrate & Kinase & Function & References \\
\hline $\begin{array}{l}\text { MAPKAPK2 } \\
\text { (MK2) }\end{array}$ & $\begin{array}{l}p 38 \alpha, p 38 \beta, p 38 \gamma \\
\text { p38 }\end{array}$ & Activates the kinase substrate & $\begin{array}{c}\text { Freshney NW et al., Cell, } 1994^{4} \\
\text { Rouse J et al., Cell, 1994 }\end{array}$ \\
\hline $\begin{array}{l}\text { MAPKAPK3 } \\
\text { (MK3) }\end{array}$ & $\begin{array}{c}\mathrm{p} 38 \alpha, \mathrm{p} 38 \beta, \mathrm{p} 38 \gamma \\
\mathrm{p} 38 \delta\end{array}$ & Activates the kinase substrate & $\begin{array}{c}\text { McLaughlin MM et al., J Biol Chem, } \\
1996^{54}\end{array}$ \\
\hline MNK1/2 & $\mathrm{p} 38 \alpha$ & Activates the kinase substrate & $\begin{array}{c}\text { Fukunaga R et al., EMBO J, } 1997^{58} \\
\text { Waskiewicz AJ et al., EMBO J, } \\
1997^{57}\end{array}$ \\
\hline MSK1/2 & $\mathrm{p} 38 \alpha$ & Activates the kinase substrate & $\begin{array}{l}\text { Deak M et al., EMBO J, } 1998^{56} \\
\text { Pierrat B et al., J Biol Chem, 199877 }\end{array}$ \\
\hline PAK6 & $\mathrm{p} 38 \alpha$ & Activates the kinase substrate & Kaur R et al., J Biol Chem, $2005^{78}$ \\
\hline PIP4Kb & $\mathrm{p} 38 \alpha$ & Inactivates the kinase substrate & Jones DR et al., Mol Cell, $2006^{79}$ \\
\hline $\begin{array}{l}\text { RPAK } \\
\text { (MK5) }\end{array}$ & $\mathrm{p} 38 \alpha, \mathrm{p} 38 \beta$ & Activates the kinase substrate & New L et al., EMBO J, $1998^{55}$ \\
\hline PKC $\varepsilon$ & p38 $\alpha, p 38 \beta$ & Completes cytokinesis & Saurin AT et al., Nat Cell Biol, $2008^{80}$ \\
\hline GSK3 $\beta$ & $\mathrm{p} 38 \alpha$ & $\begin{array}{l}\text { Inactivates the kinase } \\
\text { substrate, activates Wnt } \\
\text { pathway. }\end{array}$ & $\begin{array}{l}\text { Bikkavilli RK et al., J Cell Sci, } 2008^{60} \\
\text { Thornton TM et al., Science, } 2008^{59}\end{array}$ \\
\hline
\end{tabular}

GSK3 3 , glycogen synthase kinase 3 beta; MAPKAPK, mitogen-activated protein kinase activated protein kinase; MSK1/2, mitogen- and stress-activated protein kinase; PAK6, p21-activated kinase 6; PIP4Kb, phosphatidylinositol 5 phosphate 4-kinase; PKCE, protein kinase C epsilon type.

\section{Table 2. Substrates of p38 group members - transcription factors.}

\begin{tabular}{|c|c|c|c|}
\hline Substrate & Kinase & Function & References \\
\hline ATF2 & $\begin{array}{l}\text { p38 } \alpha, p 38 \beta \\
\text { p38 } \gamma, p 38 \delta\end{array}$ & Enhances transcriptional activity & $\begin{array}{l}\text { Cuenda A et al., EMBO J, } 1997^{81} \\
\text { Jiang Y et al., J Biol Chem, } 1997^{9}\end{array}$ \\
\hline $\mathrm{C} / \mathrm{EBP} \alpha$ & $\mathrm{p} 38 \alpha$ & Enhances transcriptional activity & Qiao L et al., J Biol Chem, $2006^{82}$ \\
\hline $\mathrm{C} / \mathrm{EBP} \beta$ & $\mathrm{p} 38 \alpha$ & Enhances transcriptional activity & $\begin{array}{l}\text { Engelman JA et al., J Biol Chem, } \\
1998^{83}\end{array}$ \\
\hline C/EBPE & p38 $\alpha$ & Enhances transcriptional activity & Williamson EA et al., Blood, $2005^{84}$ \\
\hline $\mathrm{CHOP}$ & $p 38 \alpha, p 38 \beta$ & Enhances transcriptional activity & Wang XZ et al., Science, $1996^{68}$ \\
\hline E2F4 & $\mathrm{p} 38 \alpha$ & Enhances transcriptional activity & Morillo SM et al., Mol Cell Biol, $2012^{85}$ \\
\hline Elk-1 & p38 $\alpha$ & $\begin{array}{l}\text { Enhances transcriptional activity } \\
\text { in specific cell types }\end{array}$ & $\begin{array}{c}\text { Janknecht R et al., EMBO J, } 1997^{67} \\
\text { Whitmarsh AJ et al., Mol Cell Biol, } \\
1997^{66}\end{array}$ \\
\hline $\mathrm{ER} \alpha$ & $\mathrm{p} 38 \alpha$ & $\begin{array}{l}\text { Enhances nuclear localization } \\
\text { and transcriptional activity }\end{array}$ & Lee H et al., Mol Cell Biol, $2002^{86}$ \\
\hline Fos & 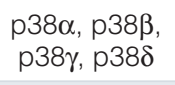 & Enhances transcriptional activity & Tanos T et al., J Biol Chem, $2005^{87}$ \\
\hline $\mathrm{FOXO3a}$ & $\mathrm{p} 38 \alpha$ & Enhances nuclear relocalization & Ho KK et al., J Biol Chem, $2012^{88}$ \\
\hline GR & $\mathrm{p} 38 \alpha$ & Enhances transcriptional activity & $\begin{array}{c}\text { Miller AL et al., Mol Endocrinol, } \\
2005^{89}\end{array}$ \\
\hline IUF1 & $p 38 \alpha, p 38 \beta$ & Enhances transcriptional activity & $\begin{array}{c}\text { Macfarlane WM et al., J Biol Chem, } \\
1997^{90}\end{array}$ \\
\hline JDP2 & $\mathrm{p} 38 \alpha$ & N/D & Katz S et al., Biochem J, $2002^{91}$ \\
\hline C-JUN & $\begin{array}{l}\text { p38 } \alpha, \text { p38 } \beta \\
\text { p38 }\end{array}$ & Enhances transcriptional activity & $\begin{array}{c}\text { Humar M et al., Int J Biochem Cell } \\
\text { Biol, } 2007^{92}\end{array}$ \\
\hline
\end{tabular}




\begin{tabular}{|c|c|c|c|}
\hline Substrate & Kinase & Function & References \\
\hline MafA & 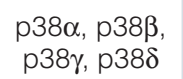 & Enhances transcriptional activity & Sii-Felice K et al., FEBS Lett, $2005^{93}$ \\
\hline MEF2A & $\begin{array}{c}\mathrm{p} 38 \alpha, \mathrm{p} 38 \beta \\
\mathrm{p} 38 \delta\end{array}$ & Enhances transcriptional activity & Zhao M et al., Mol Cell Biol, $1999^{94}$ \\
\hline MEF2C & 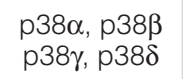 & Enhances transcriptional activity & Han J et al., Nature, $1997^{62}$ \\
\hline MEF2D & $\mathrm{p} 38 \alpha$ & $\begin{array}{l}\text { Enhances recruitment of Ash2L } \\
\text { to muscle-specific promoters }\end{array}$ & $\begin{array}{c}\text { Zhao M et al., Mol Cell Biol, } 1999^{94} \\
\text { Rampalli S et al., Nat Struct Mol Biol, } \\
2007^{73}\end{array}$ \\
\hline MITF & $\mathrm{p} 38 \alpha$ & Enhances transcriptional activity & $\begin{array}{c}\text { Mansky KC et al., J Biol Chem, } \\
2002^{95}\end{array}$ \\
\hline MRF4 & $\mathrm{p} 38 \alpha$ & Represses transcriptional activity & Suelves M et al., EMBO J, $2004^{96}$ \\
\hline NFATc 1 & $\mathrm{p} 38 \alpha$ & $\begin{array}{l}\text { Enhances transcriptional activity } \\
\text { and interaction with PU.1 }\end{array}$ & $\begin{array}{l}\text { Matsumoto M et al., J Biol Chem, } \\
\qquad 2004^{97}\end{array}$ \\
\hline NFATc4 & $\begin{array}{l}\text { p38 } \alpha, p 38 \beta \\
\text { p38 }\end{array}$ & $\begin{array}{l}\text { Represses nuclear localization } \\
\text { and transcriptional activity }\end{array}$ & Yang TT et al., Mol Cell Biol, $2002^{98}$ \\
\hline NR4A & $\mathrm{p} 38 \alpha$ & Enhances transcriptional activity & Sekine Y et al., J Cell Sci, $2011^{99}$ \\
\hline Nur77 & $\mathrm{p} 38 \alpha$ & $\begin{array}{l}\text { Disrupts interaction with p65 and } \\
\text { represses transcriptional activity }\end{array}$ & Li L et al., Nat Chem Biol, $2015^{100}$ \\
\hline Osterix & $\mathrm{p} 38 \alpha$ & $\begin{array}{l}\text { Enhances recruitment of } \\
\text { coactivators }\end{array}$ & $\begin{array}{l}\text { Ortuño MJ et al., J Biol Chem, } \\
2010^{101}\end{array}$ \\
\hline p53 & p38 $\alpha$ & $\begin{array}{c}\text { Increases protein stability and } \\
\text { apoptosis }\end{array}$ & Bulavin DV et al., EMBO J, $1999^{69}$ \\
\hline Pax6 & $\mathrm{p} 38 \alpha$ & Enhances transcriptional activity & Mikkola I et al., J Biol Chem, $1999^{102}$ \\
\hline PPAR $\alpha$ & $\mathrm{p} 38 \alpha$ & Enhances transcriptional activity & $\begin{array}{c}\text { Barger PM et al., J Biol Chem, } \\
2001^{103}\end{array}$ \\
\hline SAP1 & 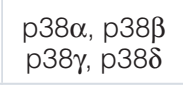 & Enhances transcriptional activity & Janknecht R et al., EMBO J, $1997^{67}$ \\
\hline Smad3 & $\mathrm{p} 38 \alpha$ & Enhances nuclear translocation & Hayes SA et al., Oncogene, $2003^{104}$ \\
\hline Snail & $\mathrm{p} 38 \alpha$ & $\begin{array}{l}\text { Increases protein stability and } \\
\text { transcriptional activity }\end{array}$ & Ryu KJ et al., Cancer Res, $2019^{105}$ \\
\hline STAT1 & $p 38 \alpha, p 38 \beta$ & Enhances transcriptional activity & $\begin{array}{c}\text { Kovarik P et al., Proc Natl Acad Sci } \\
\text { US A, 1999106 }\end{array}$ \\
\hline STAT4 & $\mathrm{p} 38 \alpha$ & Enhances transcriptional activity & Visconti R et al., Blood, 2000 ${ }^{107}$ \\
\hline TEAD4 & p38 $\alpha$ & $\begin{array}{c}\text { Enhances cytoplasmic } \\
\text { translocation and suppresses } \\
\text { transcriptional activity }\end{array}$ & Lin KC et al., Nat Cell Biol, $2017^{76}$ \\
\hline Twist1 & $\mathrm{p} 38 \alpha$ & $\begin{array}{l}\text { Increases protein stability and } \\
\text { transcriptional activity }\end{array}$ & Hong J et al., Cancer Res, 2011'108 \\
\hline USF1 & $\mathrm{p} 38 \alpha$ & Enhances transcriptional activity & Galibert MD et al., EMBO J, $2001^{71}$ \\
\hline Xbp1s & $\mathrm{p} 38 \alpha$ & $\begin{array}{l}\text { Enhances nuclear translocation } \\
\text { and transcriptional activity }\end{array}$ & Lee J et al., Nat Med, $2011^{75}$ \\
\hline \multicolumn{4}{|c|}{$\begin{array}{l}\text { ATF2, activating transcription factor 2; C/EBP, CCAAT/enhancer binding protein; CHOP, CCAAT/enhancer-binding } \\
\text { protein homologous protein; ER, estrogen receptor; GR, glucocorticoid receptor; IUF1, insulin upstream factor 1; } \\
\text { JDP2, Jun dimerization protein 2; MEF, myocyte-specific enhancer factor; MITF, microphthalmia transcription factor; } \\
\text { MRF, muscle regulatory factor; NFAT, nuclear factor of activated T cells; Pax6, paired box 6; PPAR } \alpha \text {, peroxisome } \\
\text { proliferator-activated receptor alpha; TEAD4, TEA domain family transcription factor 4; USF1, upstream transcription } \\
\text { factor 1; Xbp1s, spliced form of X-box binding protein } 1 \text {. }\end{array}$} \\
\hline
\end{tabular}


in Table 3. The SWI-SNF complex subunit BAF60 is phosphorylated and inactivated by p38 during skeletal myogenesis ${ }^{109,110}$, and EZH2, the catalytic component of the Polycomb Repressive Complex 2 (PRC2), was also found to be phosphorylated by $\mathrm{p} 38$, particularly in ER-negative breast cancer samples ${ }^{111}$. Besides its transcriptional function, dATF-2 is also involved in heterochromatin formation, and stress-induced phosphorylation of dATF-2 by p38 disrupts heterochromatin in Drosophila ${ }^{112}$.

\section{Other substrates}

Given the wide range of responses that p38 is involved in, it is not surprising that many p38 substrates cannot be so easily categorized into groups, and these miscellaneous substrates are summarized in Table 4. Some of them are involved in metabolism such as Raptor phosphorylation by $\mathrm{p} 38 \beta$, which enhances mTORC1 activity in response to arsenite-stress ${ }^{113}$, and DEPTOR (mTOR-inhibitory protein) phosphorylation by $\mathrm{p} 38 \gamma$ and $\mathrm{p} 38 \delta$, leading to its degradation and mTOR hyperactivation ${ }^{114}$. p38 $\alpha$ phosphorylation of Tip60 at $\mathrm{Thr}^{158}$ promotes senescence and DNA-damage-induced apoptosis ${ }^{115,116}$. Some p38 substrates are cell death regulators. In the ER stress response, p38 $\alpha$ locates to the lysosome and phosphorylates the chaperone-mediated autophagy (CMA) receptor LAMP2A, leading to activation of CMA and thus protecting cells from ER stress-induced death ${ }^{117}$.

\section{Biological functions of the p38 pathway}

Embryo development

p38 $\alpha$ is required for embryo development, since the mouse Mapk14 ${ }^{--}$embryo dies between embryonic days (E) 10.5 and $12.5^{118-121}$. Mutant mice with a single $\mathrm{Thr}^{180}$ to Ala mutation or with the double T180A Y182F mutation are also embryonic lethal ${ }^{122,123}$. Surprisingly, given the importance of the dual phosphorylation for complete $\mathrm{p} 38$ activation, substitution of $\mathrm{Tyr}^{182}$ with Phe results in mice that have reduced p38 signaling but are nevertheless viable ${ }^{123}$, although this is consistent with previous studies showing that the $\mathrm{p} 38$ phosphorylated on $\mathrm{Thr}^{180}$ alone retains some activity in vitro ${ }^{37}$. Histological analysis demonstrates that $\mathrm{p} 38 \alpha$ is required for placental angiogenesis, but not embryonic cardiovascular development, and tetraploid rescue of the placental defect in Mapk14 $4^{--}$embryos confirmed that $\mathrm{p} 38 \alpha$ is

Table 3. Substrates of p38 group members - transcriptional regulators.

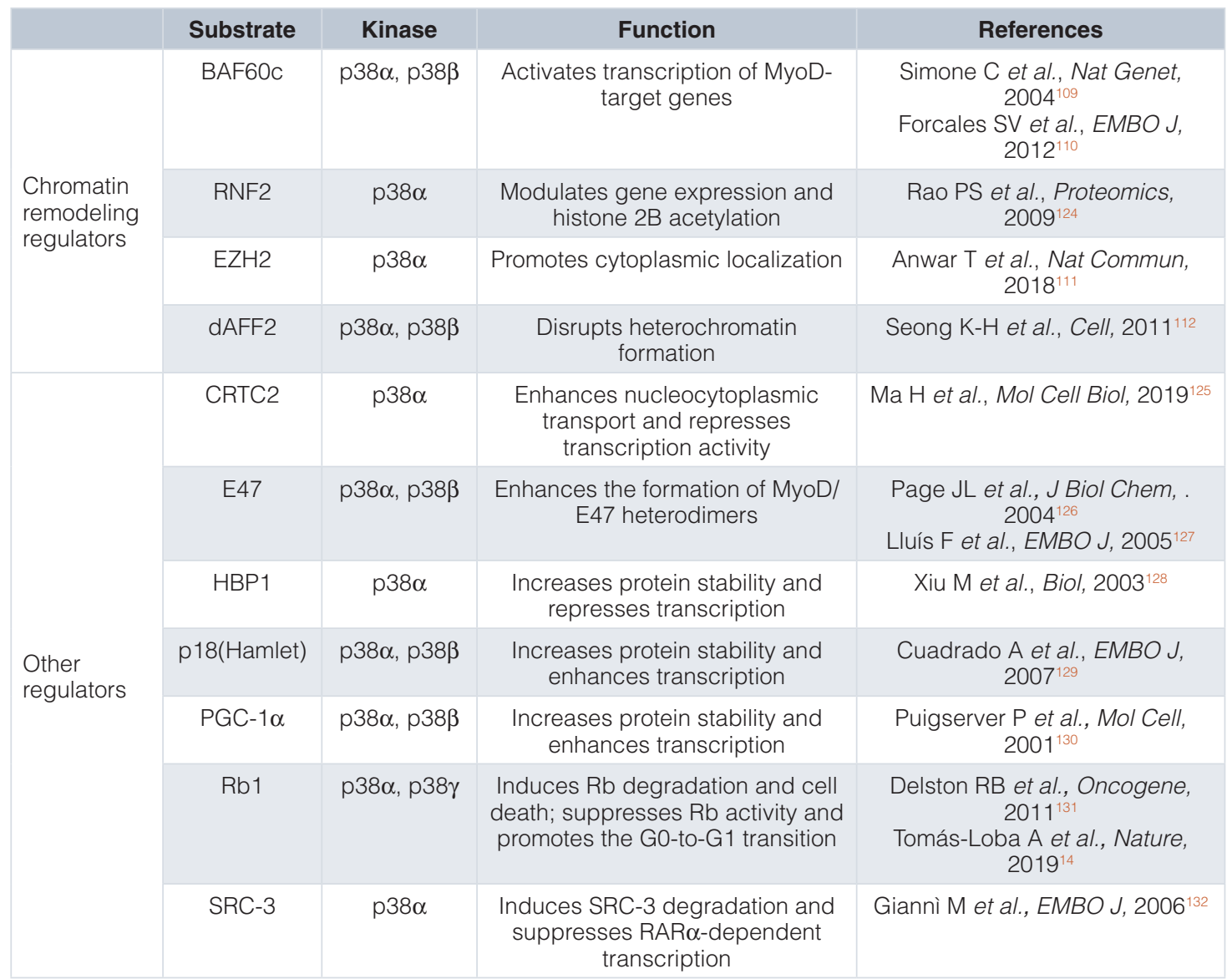

CRTC2, CREB-regulated transcription coactivator 2; HBP1, HMG-box transcription factor 1; PGC-1 $\alpha$, peroxisome proliferator-activated receptor gamma co-activator 1 alpha; RAR, retinoic acid receptor; RNF2, ring finger protein 2. 
Table 4. Substrates of p38 group members - others.

\begin{tabular}{|c|c|c|c|c|}
\hline & Substrate & Kinase & Function & References \\
\hline \multirow{5}{*}{$\begin{array}{l}\text { Cell-cycle } \\
\text { regulators }\end{array}$} & Cdc25A & $\mathrm{p} 38 \alpha$ & Increases protein stability & Goloudina A et al., Cell Cycle, 2003 ${ }^{133}$ \\
\hline & Cdc25B & $\mathrm{p} 38 \alpha$ & Increases protein stability & Lemaire M et al., Cell Cycle, 2006 ${ }^{134}$ \\
\hline & Cyclin D1 & $\mathrm{p} 38 \alpha$ & $\begin{array}{l}\text { Causes ubiquitination and degradation } \\
\text { of cyclin D1 }\end{array}$ & Casanovas O et al., J Biol Chem, 2000 \\
\hline & Cyclin D3 & 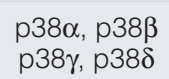 & $\begin{array}{c}\text { Causes ubiquitination and degradation } \\
\text { of cyclin D3 }\end{array}$ & Casanovas O et al., Oncogene, $2004^{136}$ \\
\hline & p57kip2 & p38 $\alpha$ & $\begin{array}{c}\text { Enhances interaction with CDKs and } \\
\text { inhibits CDKs }\end{array}$ & Joaquin $\mathrm{M}$ et al., EMBO J, $2012^{137}$ \\
\hline \multirow{5}{*}{$\begin{array}{l}\text { Cell-death } \\
\text { regulators }\end{array}$} & Bax & p38 $\alpha$ & $\begin{array}{l}\text { Prevents Bcl-2-Bax heterodimer } \\
\text { formation, enhances apoptosis }\end{array}$ & Min $\mathrm{H}$ et al., Mol Carcinog, $2012^{138}$ \\
\hline & BimEL & $\mathrm{p} 38 \alpha$ & Enhances apoptosis & Cai B et al., J Biol Chem, 2006 ${ }^{139}$ \\
\hline & Caspase-3 & $\mathrm{p} 38 \alpha$ & $\begin{array}{c}\text { Inhibits caspase- } 3 \text { activity and } \\
\text { apoptosis }\end{array}$ & $\begin{array}{c}\text { Alvarado-Kristensson } \mathrm{M} \text { et al., J Exp Med, } \\
2004^{140}\end{array}$ \\
\hline & Caspase-8 & $\mathrm{p} 38 \alpha$ & $\begin{array}{c}\text { Inhibits caspase- } 8 \text { activity and } \\
\text { apoptosis }\end{array}$ & $\begin{array}{c}\text { Alvarado-Kristensson } \mathrm{M} \text { et al., J Exp Med, } \\
2004^{140}\end{array}$ \\
\hline & Caspase-9 & $\mathrm{p} 38 \alpha$ & $\begin{array}{c}\text { Inhibits caspase- } 9 \text { activity and } \\
\text { apoptosis }\end{array}$ & Seifert A et al., Cell Signal, $2009^{141}$ \\
\hline \multirow{10}{*}{$\begin{array}{l}\text { DNA/RNA } \\
\text { binding proteins }\end{array}$} & Cdt1 & $\mathrm{p} 38 \alpha, \mathrm{p} 38 \beta$ & Increases protein stability & $\begin{array}{l}\text { Chandrasekaran S et al., Mol Cell Biol, } \\
2011^{142}\end{array}$ \\
\hline & Drosha & $\mathrm{p} 38 \alpha$ & $\begin{array}{l}\text { Enhances nuclear export and } \\
\text { degradation }\end{array}$ & Yang Q et al., Mol Cell, $2015^{143}$ \\
\hline & FBP2 & $\mathrm{p} 38 \alpha$ & $\begin{array}{l}\text { Promotes prothrombin mRNA } 3 \text { ' end } \\
\text { processing }\end{array}$ & Danckwardt S et al., Mol Cell, $2011^{144}$ \\
\hline & FBP3 & p38 $\alpha$ & $\begin{array}{l}\text { Promotes prothrombin mRNA } 3 \text { ' end } \\
\text { processing }\end{array}$ & Danckwardt S et al., Mol Cell, $2011^{144}$ \\
\hline & $\mathrm{H} 2 \mathrm{AX}$ & $\mathrm{p} 38 \alpha, \mathrm{p} 38 \beta$ & $\begin{array}{l}\text { Promotes serum starvation-induced } \\
\text { apoptosis }\end{array}$ & Lu C et al., FEBS Lett, 2008 \\
\hline & $\mathrm{H} 3$ & p38 $\alpha$ & $\mathrm{N} / \mathrm{D}$ & Zhong SP et al., J Biol Chem, 2000 ${ }^{146}$ \\
\hline & HuR & p38 $\alpha, p 38 \beta$ & $\begin{array}{l}\text { Enhances cytoplasmic accumulation } \\
\text { and increases mRNA stability }\end{array}$ & Lafarga V et al., Mol Cell Biol, $2009^{147}$ \\
\hline & KSRP & $\mathrm{p} 38 \alpha, \mathrm{p} 38 \beta$ & $\begin{array}{l}\text { Prevents KSRP-mediated ARE-directed } \\
\text { mRNA decay }\end{array}$ & Briata P et al., Mol Cell, $2005^{148}$ \\
\hline & Rps27 & $\mathrm{p} 38 \alpha$ & $\mathrm{N} / \mathrm{D}$ & Knight JD et al., Skelet Muscle, $2012^{149}$ \\
\hline & SPF45 & p38 $\alpha$ & $\begin{array}{c}\text { Inhibits Fas alternative splicing (exon } 6 \\
\text { exclusion) }\end{array}$ & Al-Ayoubi AM et al., Mol Cell Biol, 2012 \\
\hline \multirow{3}{*}{$\begin{array}{l}\text { Endocytosis } \\
\text { regulators }\end{array}$} & EEA1 & $\mathrm{p} 38 \alpha$ & $\begin{array}{c}\text { Promotes recruitment to endocytic } \\
\text { membranes and enhances MOR } \\
\text { endocytosis }\end{array}$ & Macé G et al., EMBO J, $2005^{151}$ \\
\hline & Rabenosyn-5 & $\mathrm{p} 38 \alpha$ & $\begin{array}{c}\text { Promotes recruitment to endocytic } \\
\text { membranes and enhances MOR } \\
\text { endocytosis }\end{array}$ & Macé G et al., EMBO J, $2005^{151}$ \\
\hline & GDI-2 & $\mathrm{p} 38 \alpha$ & $\begin{array}{c}\text { Enhances GDI:Rab5 complex formation } \\
\text { and modulates endocytosis }\end{array}$ & Cavalli V et al., Mol Cell, $2001^{152}$ \\
\hline \multirow{5}{*}{$\begin{array}{l}\text { MAPK pathway } \\
\text { regulator }\end{array}$} & JIP4 & p38 $\alpha$ & Enhances p38 activity & Kelkar N et al., Mol Cell Biol, $2005^{153}$ \\
\hline & Tip60 & $\mathrm{p} 38 \alpha$ & $\begin{array}{c}\text { Enhances the pro-senescent function } \\
\text { of Tip60 }\end{array}$ & Zheng $\mathrm{H}$ et al., Mol Cell, $2013^{115}$ \\
\hline & TAB1 & p38 $\alpha$ & Inhibits TAK1 activity & Cheung PC et al., EMBO J, $2003^{154}$ \\
\hline & TAB3 & $\mathrm{p} 38 \alpha$ & Inhibits TAK1 activity & Mendoza $\mathrm{H}$ et al., Biochem J, $2008^{155}$ \\
\hline & FRS2 & p38 $\alpha$ & Downregulates FGF1-induced signaling & Zakrzewska M et al., Int J Mol Sci, $2019^{156}$ \\
\hline
\end{tabular}




\begin{tabular}{|c|c|c|c|c|}
\hline & Substrate & Kinase & Function & References \\
\hline \multirow{7}{*}{$\begin{array}{l}\text { Membrane } \\
\text { proteins }\end{array}$} & EGFR & p38 $\alpha$ & Induces EGFR internalization & Winograd-Katz SE et al., Oncogene, 2006 157 \\
\hline & FGFR1 & $\mathrm{p} 38 \alpha$ & $\begin{array}{l}\text { Regulates translocation of exogenous } \\
\text { FGF1 into the cytosol/nucleus }\end{array}$ & Sørensen V et al., Mol Cell Biol, 2008 ${ }^{158}$ \\
\hline & Nav1.6 & $\mathrm{p} 38 \alpha$ & $\begin{array}{c}\text { Promotes interaction with NEDD-4 and } \\
\text { protein degradation }\end{array}$ & Gasser A et al., J Biol Chem, 2010159 \\
\hline & NHE1 & p38 $\alpha$ & Induces intracellular alkalinization & Khaled AR et al., Mol Cell Biol, 2001 ${ }^{160}$ \\
\hline & PLA2 & $\mathrm{p} 38 \alpha$ & N/D & Börsch-Haubold AG et al., J Biol Chem, $1998^{161}$ \\
\hline & TACE & $p 38 \alpha, p 38 \beta$ & $\begin{array}{c}\text { Increases TACE-mediated ectodomain } \\
\text { shedding and TGF-alpha family ligand } \\
\text { release }\end{array}$ & Xu P et al., Mol Cell, 2010'62 \\
\hline & ZAP70 & p38 $\alpha$ & $\begin{array}{l}\text { Phosphorylation of ZAP70 increases } \\
\text { stability of T cell receptor }\end{array}$ & $\begin{array}{c}\text { Giardino Torchia ML et al., Proc Natl Acad Sci } \\
\text { US A, } 2018^{41}\end{array}$ \\
\hline \multirow{9}{*}{$\begin{array}{l}\text { Structure } \\
\text { proteins }\end{array}$} & Caldesmon & p38 $\alpha$ & N/D & Hedges JC et al., Am J Physiol, $1998^{163}$ \\
\hline & Hsp27 & $\mathrm{p} 38 \alpha$ & N/D & Knight JD et al., Skelet Muscle, $2012^{149}$ \\
\hline & Keratin 8 & $\mathrm{p} 38 \alpha$ & $\begin{array}{l}\text { Regulates cellular keratin filament } \\
\text { reorganization }\end{array}$ & Ku NO et al., J Biol Chem, $2002^{164}$ \\
\hline & Lamin B1 & p38 $\alpha$ & Enhances lamin B1 accumulation & Barascu A et al., EMBO J, $2012^{165}$ \\
\hline & Paxillin & $\mathrm{p} 38 \alpha$ & $\begin{array}{l}\text { Required for NGF-induced neurite } \\
\text { extension of PC-12 cells }\end{array}$ & Huang C et al., J Cell Biol, 2004 ${ }^{166}$ \\
\hline & Stathmin & p388 & N/D & $\begin{array}{c}\text { Parker CG et al., Biochem Biophys Res } \\
\text { Commun, 1998 }\end{array}$ \\
\hline & SAP97 & p38 $\gamma$ & $\begin{array}{l}\text { Modulating the association of this } \\
\text { protein with other cytoskeleton proteins }\end{array}$ & Sabio G et al., EMBO J, $2005^{168}$ \\
\hline & Tau & 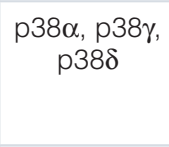 & $\begin{array}{c}\text { Enhances formation of paired helical } \\
\text { filaments } \\
\text { Inhibits amyloid- } \beta \text { toxicity in Alzheimer's } \\
\text { mice }\end{array}$ & $\begin{array}{c}\text { Reynolds CH et al., J Neurochem, } 1997^{169} \\
\text { Ittner A et al., Science, 2016 }\end{array}$ \\
\hline & Tensin 1 & $\mathrm{p} 38 \alpha$ & $\begin{array}{l}\text { Regulates the binding specificity of } \\
\text { tensin } 1 \text { to different proteins }\end{array}$ & Hall EH et al., Mol Cell Proteomics, 2010 \\
\hline \multirow{9}{*}{ Others } & DEPTOR & 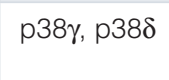 & $\begin{array}{c}\text { Enhances degradation and mTOR } \\
\text { hyperactivation }\end{array}$ & González-Terán B et al., Nat Commun, $2016^{114}$ \\
\hline & GS & p38 $\beta$ & $\begin{array}{l}\text { Required for subsequent } \\
\text { phosphorylation to inhibit enzyme activity }\end{array}$ & Kuma Y et al., Biochem J, 2004 ${ }^{172}$ \\
\hline & LAMP2A & p38 $\alpha$ & $\begin{array}{c}\text { Activates chaperone-mediated } \\
\text { autophagy }\end{array}$ & Li W et al., Nat Commun, $2017^{117}$ \\
\hline & Parkin & $\mathrm{p} 38 \alpha$ & $\begin{array}{l}\text { Decreases its interaction with PINK1 } \\
\text { and suppresses mitophagy }\end{array}$ & Chen J et al., Cell Death Dis, $2018^{173}$ \\
\hline & $\mathrm{p} 47^{\text {phox }}$ & $\mathrm{p} 38 \alpha$ & $\begin{array}{l}\text { Promotes NADPH oxidase activation } \\
\text { and superoxide production }\end{array}$ & Makni-Maalej K et al., J Immunol, $2012^{174}$ \\
\hline & p62 & 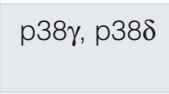 & Enhances mTORC1 activity & $\begin{array}{l}\text { Linares JF et al., Cell Rep, } 2015^{175} \\
\quad \text { Koh A et al., Cell, 2018 }\end{array}$ \\
\hline & Raptor & $\mathrm{p} 38 \beta$ & $\begin{array}{c}\text { Enhances mTORC1 activity in response } \\
\text { to arsenite stress }\end{array}$ & Wu X-N et al., J Biol Chem, $2011^{113}$ \\
\hline & Rpn2 & p38 $\alpha$ & Inhibits proteasome activity & Lee SH et al., J Biol Chem, 2010177 \\
\hline & Siah2 & $\mathrm{p} 38 \alpha$ & $\begin{array}{c}\text { Increases Siah2-mediated degradation } \\
\text { of PHD3 }\end{array}$ & Khurana A et al., J Biol Chem, $2006^{178}$ \\
\hline
\end{tabular}

CDK, cyclin-dependent kinase; EGFR, epidermal growth factor receptor; FBP1, far upstream binding protein; FGF1, fibroblast growth factor 1; FGFR1, fibroblast growth factor receptor 1; FRS2, fibroblast growth factor receptor substrate 2; GDI, GDP dissociation inhibitor; KSRP, hnRNPK-homology type splicing regulatory protein; MAPK, mitogen-activated protein kinase; mTORC1, mammalian target of rapamycin complex 1; NADPH, nicotinamide adenine dinucleotide phosphate; NGF, nerve growth factor; NHE1, Na $/ \mathrm{H}^{+}$exchanger isoform 1; PHD3, prolyl hydroxylase 3; PLA2, phospholipase A2; SAP97, synapse-associated protein 97; TAB, transforming growth factor- $\beta$-activated protein kinase-1-binding protein; TACE, tumor necrosis factor-alpha-converting enzyme; TAK1, transforming growth factor $\beta$-activated kinase 1 ; TGF, transforming growth factor. 
essential for extraembryonic development ${ }^{120,121}$. Given the important role that p38 and MK2 plays in regulating TNF-induced cell

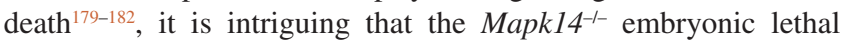
phenotype is very similar to that observed in other mice with defects in the TNF death pathway. Caspase-8, FADD, and cFLIP knock-out mice also die at E10.5, and this is due to TNFdependent endothelial cell death and disruption of the vasculature in the yolk sac ${ }^{183,184}$. Other p38 isoforms are not necessary for embryo development, but $\mathrm{p} 38 \alpha$ and $\mathrm{p} 38 \beta$ have overlapping

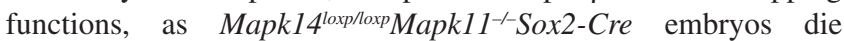
before E16.5 with spina bifida that correlates with neural hyperproliferation and increased apoptosis in the liver, which was not

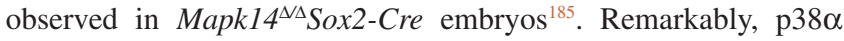
appears to have a very specific function during embryogenesis because when $\mathrm{p} 38 \alpha$ was replaced by $\mathrm{p} 38 \beta$ in the Mapk14 chromosomal locus, which thereby placed $\mathrm{p} 38 \beta$ under the control of the endogenous $\mathrm{p} 38 \alpha$ promoter, it was unable to rescue the embryonic lethality induced by loss of $\mathrm{p} 38 \alpha^{185}$.

\section{Immune responses}

p38 is activated by many inflammatory stimuli, and its activity is important for inflammatory responses. Macrophage-specific deletion of Mapk14 inhibits inflammatory cytokine production and protects mice from CLP-induced sepsis ${ }^{186}$. p38 $\alpha$ controls the production of inflammatory cytokines, such as TNF and IL-6, at many levels. It directly phosphorylates transcription factors, such as MEF2C ${ }^{62,186}$, and regulators of mRNA stability, such as hnRNPK-homology $(\mathrm{KH})$ type splicing regulatory protein $(\mathrm{KSRP})^{187}$. MEF2C appears to play an anti-inflammatory role in endothelial cells in vivo ${ }^{188}$. Via MK2/MK3, p38 also upregulates cytokine mRNA transcription by the serum response transcription factor (SRF) ${ }^{189}$, and similarly, via MK2/MK3, p38 regulates mRNA stability by phosphorylating and inactivating TTP/Zfp36, a protein that promotes rapid turnover of AU-rich mRNAs, many of which are cytokine mRNAs ${ }^{187,190}$. p38 activation also induces the expression of inflammatory mediators such as COX-2, MMP9, iNOS, and VCAM-1, which are involved in tissue remodeling and oxidation regulation ${ }^{191-194}$. The p38 pathway also regulates adaptive immunity. p38 $\alpha$ participates in antigen processing in $\mathrm{CD}^{+} \mathrm{CDCs}^{195}$, and ZAP70-mediated $\mathrm{p} 38 \alpha / \beta$ activation is important for $\mathrm{T}$ cell homeostasis and function ${ }^{18}$. In $\mathrm{B}$ cells, $\mathrm{p} 38 \alpha$ is important for CD40-induced gene expression and proliferation of $\mathrm{B}$ cells ${ }^{196}$, and the $\mathrm{p} 38 \alpha-\mathrm{MEF} 2 \mathrm{c}$ axis is believed to be necessary for germinal center B (GCB) cell proliferation and survival ${ }^{197,198}$. Excessive activation of $\mathrm{p} 38 \alpha$ has been observed in many inflammatory diseases, such as inflammatory bowel disease (IBD), asthma, rheumatoid arthritis, and steatohepatitis ${ }^{199-201}$. The other members of the p38 family also play roles in immune responses. For example, p38 $\gamma$ and p38 $\delta$ are required for neutrophil migration to damaged liver in non-alcoholic fatty liver disease $\mathrm{e}^{202}$ and inhibition of eukaryotic elongation factor 2 in LPS-induced liver damage ${ }^{203} \cdot \mathrm{p} 38 \delta$ is required for neutrophil accumulation in acute lung injury ${ }^{204}$. These observations, and the role that $\mathrm{p} 38 \mathrm{~s}$ play in TNF production, led to enormous pharmaceutical efforts to develop p38 inhibitors to treat chronic inflammatory diseases. However, unfortunately, these drugs were not efficacious in these diseases ${ }^{205}$.

\section{Cell cycle}

p38 has been implicated in G1 and G2/M phases of the cell cycle in several studies. The addition of activated recombinant $\mathrm{p} 38 \alpha$ caused mitotic arrest in vitro, and an inhibitor of $\mathrm{p} 38 \alpha / \beta$ suppressed activation of the checkpoint by nocodazole in NIH3T3 cells ${ }^{206}$. G1 arrest caused by Cdc42 overexpression is also dependent on $\mathrm{p} 38 \alpha$ in NIH3T3 cells ${ }^{207}$. Besides, p38 $\gamma$ is specially required for gamma-irradiation-induced G2 arrest ${ }^{208}$. The link between p38 and cell cycle control has been proposed through the regulation of several p38 substrates. Both p38 $\alpha$ and p38 $\gamma$ regulate cell cycle progression via $\mathrm{Rb}$ but in opposite directions ${ }^{14,209}$. HBP1 represses the expression of cell cycle regulatory genes during cell cycle arrest in a p38-dependent manner ${ }^{210} ;$ p53 and p21 activation by $\mathrm{p} 38 \alpha$ prevented G1 progression through blockade of CDK activity ${ }^{211,212}$. The p38 pathway is also involved in cell cycle progress, as it is essential for self-renewal of mouse male germline stem cells ${ }^{213}$ and its regulation of G1-length plays a role in cell size uniformity ${ }^{214}$.

\section{Cell differentiation}

Participation of p38 in cell differentiation has been reported in certain cell types. p38 $\alpha$ activity is essential for neuronal differentiation in PC-12 cells and EPO-induced differentiation in SKT6 cells ${ }^{20,215}$. Treatment of 3T3-L1 fibroblasts with specific p38 $\alpha / \beta$ inhibitors prevents their differentiation into adipocytes by reducing $\mathrm{C} / \mathrm{EBP} \beta$ phosphorylation ${ }^{83}$, and $\mathrm{p} 38 \alpha$-dependent phosphorylation of MEF2C and BAF60 is critical for myogenic differentiation ${ }^{110,216}$. Intestinal epithelial cell-specific deletion of $\mathrm{p} 38 \alpha$ also influences goblet cell differentiation in a Notchdependent manner ${ }^{200}$.

\section{Cell metabolism}

p38 group members participate in many cellular events related to metabolism. The p38 $\beta$-PRAK axis specifically phosphorylates Rheb and suppresses mTORC1 activity under energy depletion conditions ${ }^{22}$. DEPTOR, an inhibitor of mTORC, can be phosphorylated by $\mathrm{p} 38 \gamma$ and $\mathrm{p} 38 \delta$, leading to its degradation ${ }^{123}$. Meanwhile, p38 directly phosphorylated p62 to enhance mTORC1 activity in response to amino acids $^{175}$. In brown adipocytes, $\mathrm{p} 38 \alpha$ functions as a central mediator in $\beta$-adrenergic-induced UCP1 expression ${ }^{217,218}$, while in white adipocytes, p38 $\alpha$ inactivation leads to elevated white-to-beige adipocyte reprogramming and resistance to diet-induced obesity ${ }^{219,220}$. In hepatocytes, p38 $\alpha$ controls lipolysis and protects against nutritional steatohepatitis. Thus, mice with hepatocyte-specific loss of $\mathrm{p} 38 \alpha$ developed more severe steatohepatitis than wild type mice when fed high-fat or -cholesterol diets. Intriguingly, macrophage specific deletion of p38 had the opposite effect in the same high-fat diets and resulted in less steatohepatitis than in wild type mice, which probably reflects the inflammatory role of p38 in macrophages ${ }^{199}$. p38 $\alpha$ also directly phosphorylates Xbp1s to enhance its nuclear migration for maintaining glucose homeostasis in obesity ${ }^{75}$. However, p38 $\alpha$ also functions as a negative regulator of AMPK signaling in maintaining gluconeogenesis, and hepatic p38 $\alpha$ could be a drug target for hyperglycemia ${ }^{221}$. It was also reported that p38 $\gamma$ directly phosphorylated p62 under imidazole propionate stimulation to promote mTORC1 activity in hepatocytes ${ }^{176}$. 
Interestingly, AMPK also triggers the recruitment of $\mathrm{p} 38 \alpha$ to scaffold protein TAB1 for $\mathrm{p} 38 \alpha$ autoactivation in human T cells ${ }^{222}$.

\section{Cell senescence}

p38 $\alpha$ appears to play a pivotal role in senescence. Constitutive activation of the p38 pathway by active MKK3 or MKK6 induces senescence in several cell types ${ }^{223,224}$, and $\mathrm{p} 38 \alpha$ activity is responsible for senescence induced by multiple stimuli, such as telomere shortening ${ }^{225,226}, \mathrm{H}_{2} \mathrm{O}_{2}$ exposure ${ }^{227,228}$, and chronic oncogene activation $^{19,223,229} \cdot \mathrm{p} 38 \alpha / \beta$-specific inhibitors have been successfully used to prevent cellular senescence in cultivated human corneal endothelial cells ${ }^{230}$. Since cellular senescence is considered a defense strategy against oncogene activation, the p38 pathway plays important roles in tumorigenesis ${ }^{231}$. Meanwhile, p38 $\alpha$ activity is important for senescence-associated secretory phenotype (SASP), and its inhibition markedly reduces the secretion of most SASP factors, suggesting multiple roles for the p38 pathway in senescence ${ }^{232-235}$.

\section{Cell survival and death}

The role of the p38 pathway in cell fate is cell type and stimulus dependent. For example, p38 $\alpha$ becomes activated upon NGF withdrawal in PC-12 cells, and $\mathrm{p} 38 \alpha$ activated by overexpression of MKK3 induced apoptosis in NGF differentiated PC-12 cells ${ }^{211}$. Similarly, inhibition of p38 with PD169316 blocked NGF withdrawal-induced apoptosis in PC-12 cells ${ }^{236,237}$. The interplay between the p38 pathway and caspases, the central regulators/executors of apoptosis, is complicated because p38 $\alpha$ activity can be elevated in a caspase-dependent manner in death stimulus treated cells ${ }^{238,239}$, and caspase activity can also be elevated in MKK6E (dominant active form) overexpressed cells $^{239,240}$. In contrast, inhibition of caspase- 8 and caspase-3 by $\mathrm{p} 38 \alpha$-mediated phosphorylation in neutrophils was also reported $^{140}$. Recent studies show that p38-activated MK2 directly phosphorylates RIPK1 in TNF-treated cells or pathogen-infected cells, limiting TNF-induced cell death ${ }^{180-182}$. This represents an interesting link between cytokine production induced by TNF and cell death because TNF-induced MK2/MK3 phosphorylation of tristetraprolin/Zfp36 inactivates it and leads to increased stability of cytokine mRNAs${ }^{190}$. Aberrant p38 $\alpha$ activity is observed in many tumor cells, and inhibition of $\mathrm{p} 38 \alpha / \beta$ enhances cell death in these cells ${ }^{241,242}$.

\section{Perspectives}

p38 is one of the most researched of all proteins, let alone kinases, and a search in PubMed for p38 MAPK or p38 kinase returns more than 36,000 publications, which is a higher number than some proteins listed in a review of the "top 10" most studied genes $^{243}$. By contrast, searches for the kinases Raf and Src return about 17,000 and 25,000 hits, respectively. In 2018, there were more than 2,000 publications that mention p38, and it is clearly impractical to summarize such a vast amount of literature. As might be surmised from the preceding commentary, the studies are on a wide range of topics; however, the publications are more concentrated in some areas than others. The role of the p38 pathway in cancers $(>10,000)^{244-246}$, inflammation $(>8,000)^{247-249}$, and infections $(>3,600)^{250,251}$ was intensively studied. About 1,600 publications include the specific term "p38 inhibitor". This reflects the previously mentioned enormous interest of the pharmaceutical industry in developing p38 inhibitors to treat chronic inflammatory diseases, such as rheumatoid arthritis. Yet other publications report natural products that can activate or inhibit p38, with the ultimate aim of using them clinically $^{252-258}$. In 2011, the European Commission approved Esbriet (pirfenidone), which was described as a p38 $\gamma$ inhibitor, for the treatment of idiopathic pulmonary fibrosis ${ }^{259}$. However, when this drug was approved by the FDA in 2014 for treating the same disease, it was described as a compound that acts on multiple pathways. In 2008, there were 27 clinical trials listed testing the use of p38 inhibitors in inflammatory disease settings ${ }^{205}$, while a search today for p38 inhibitors in clinicaltrials.gov returns 44 studies for conditions as diverse as pain, asthma, cognitive impairment, rheumatoid arthritis, cancer, myelodysplastic syndrome, and depression (Table 5). This indicates that there remains clinical interest in targeting the pathway

Table 5. Clinical trials of p38 inhibitors.

\begin{tabular}{|l|l|l|l|l|}
\hline Drug & Target & Condition or disease & Status & NCT number \\
\hline ARRY-371797 & p38 & Ankylosing spondylitis & Phase 2 & NCT00811499 \\
\hline ARRY-371797 & p38 & Dental pain & Phase 2 & NCT00542035 \\
NCT00663767
\end{tabular}




\begin{tabular}{|c|c|c|c|c|}
\hline Drug & Target & Condition or disease & Status & NCT number \\
\hline BMS-582949 & p38 $\alpha$ & Vascular diseases (atherosclerosis) & Phase 2 & NCT00570752 \\
\hline CHF6297 & $\mathrm{p} 38 \alpha$ & $\begin{array}{l}\text { Chronic obstructive pulmonary } \\
\text { disease }\end{array}$ & Phase 1/2 & NCT02815488 \\
\hline $\begin{array}{l}\text { Losmapimod } \\
\text { (GS856553) }\end{array}$ & $\mathrm{p} 38 \alpha / \beta$ & Acute coronary syndrome & $\begin{array}{l}\text { Phase } \\
1 / 2 / 3\end{array}$ & $\begin{array}{l}\text { NCT01756495 } \\
\text { NCT02145468 } \\
\text { NCT00910962 }\end{array}$ \\
\hline $\begin{array}{l}\text { Losmapimod } \\
\text { (GS856553) }\end{array}$ & $\mathrm{p} 38 \alpha / \beta$ & $\begin{array}{l}\text { Chronic obstructive pulmonary } \\
\text { disease }\end{array}$ & Phase 2 & $\begin{array}{l}\text { NCT00642148 } \\
\text { NCT01541852 }\end{array}$ \\
\hline $\begin{array}{l}\text { Losmapimod } \\
\text { (GS856553) }\end{array}$ & $\mathrm{p} 38 \alpha / \beta$ & Depressive disorder, major & Phase 2 & $\begin{array}{l}\text { NCT00976560 } \\
\text { NCT00569062 }\end{array}$ \\
\hline $\begin{array}{l}\text { Losmapimod } \\
\text { (GS856553) }\end{array}$ & $\mathrm{p} 38 \alpha / \beta$ & Glomerulosclerosis, focal segmental & Phase 2 & NCT02000440 \\
\hline $\begin{array}{l}\text { Losmapimod } \\
\text { (GS856553) }\end{array}$ & $\mathrm{p} 38 \alpha / \beta$ & Pain, neuropathic & Phase 2 & $\begin{array}{l}\text { NCT01110057 } \\
\text { NCT00969059 }\end{array}$ \\
\hline LY3007113 & p38 & Metastatic cancer & Phase 1 & NCT01463631 \\
\hline $\begin{array}{l}\text { Neflamapimod } \\
\text { (VX-745) }\end{array}$ & p38 $\alpha$ & Alzheimer's disease & Phase 2 & $\begin{array}{l}\text { NCT03402659 } \\
\text { NCT02423200 } \\
\text { NCT02423122 }\end{array}$ \\
\hline $\begin{array}{l}\text { Neflamapimod } \\
\text { (VX-745) }\end{array}$ & p38 $\alpha$ & Dementia with Lewy bodies & Recruiting & NCT04001517 \\
\hline $\begin{array}{l}\text { P38 inhibitor } \\
\text { (4) }\end{array}$ & p38 & Rheumatoid arthritis & Phase 2 & $\begin{array}{l}\text { NCT00303563 } \\
\text { NCT00316771 }\end{array}$ \\
\hline PF-03715455 & $\mathrm{p} 38 \alpha$ & Asthma & Phase 2 & NCT02219048 \\
\hline PF-03715455 & p38 $\alpha$ & $\begin{array}{l}\text { Chronic obstructive pulmonary } \\
\text { disease }\end{array}$ & Phase 2 & NCT02366637 \\
\hline PF-03715455 & $\mathrm{p} 38 \alpha$ & Healthy & Phase 1 & NCT01226693 \\
\hline PH-797804 & $\mathrm{p} 38 \alpha / \beta$ & Rheumatoid arthritis & Phase 2 & $\begin{array}{l}\text { NCT00383188 } \\
\text { NCT00620685 }\end{array}$ \\
\hline $\begin{array}{l}\text { Ralimetinib } \\
\text { (LY2228820) }\end{array}$ & $\mathrm{p} 38 \alpha / \beta$ & Adult glioblastoma & Phase $1 / 2$ & NCT02364206 \\
\hline $\begin{array}{l}\text { Ralimetinib } \\
\text { (LY2228820) }\end{array}$ & $\mathrm{p} 38 \alpha / \beta$ & Advanced cancer & Phase 1 & NCT01393990 \\
\hline $\begin{array}{l}\text { Ralimetinib } \\
\text { (LY2228820) }\end{array}$ & $\mathrm{p} 38 \alpha / \beta$ & $\begin{array}{l}\text { Epithelial ovarian cancer Fallopian } \\
\text { tube cancer Primary peritoneal cancer }\end{array}$ & Phase 1/2 & NCT01663857 \\
\hline $\begin{array}{l}\text { Ralimetinib } \\
\text { (LY2228820) }\end{array}$ & $\mathrm{p} 38 \alpha / \beta$ & $\begin{array}{l}\text { Postmenopausal metastatic breast } \\
\text { cancer }\end{array}$ & Phase 2 & NCT02322853 \\
\hline SB-681323 & p38 & Acute lung injury & Phase 2 & NCT00996840 \\
\hline SB-681323 & p38 & Coronary heart disease & Phase 2 & NCT00291902 \\
\hline SB-681323 & p38 & $\begin{array}{l}\text { Chronic obstructive pulmonary } \\
\text { disease }\end{array}$ & Phase 1/2 & $\begin{array}{l}\text { NCT00564746 } \\
\text { NCT00144859 }\end{array}$ \\
\hline SB-681323 & p38 & Pain, neuropathic & Phase 2 & NCT00390845 \\
\hline SB-681323 & p38 & Rheumatoid arthritis Inflammation & Phase 1/2 & $\begin{array}{l}\text { NCT00419809 } \\
\text { NCT00439881 } \\
\text { NCT00134693 }\end{array}$ \\
\hline $\begin{array}{l}\text { Talmapimod } \\
\text { (SCIO-469) }\end{array}$ & p38 $\alpha$ & $\begin{array}{l}\text { Bone marrow diseases } \\
\text { Myelodysplastic syndromes } \\
\text { Hematologic diseases Bone marrow } \\
\text { neoplasms }\end{array}$ & Phase 2 & NCT00113893 \\
\hline $\begin{array}{l}\text { Talmapimod } \\
\text { (SCIO-469) }\end{array}$ & p38 $\alpha$ & Multiple myeloma & Phase 2 & $\begin{array}{l}\text { NCT00095680 } \\
\text { NCT00087867 }\end{array}$ \\
\hline $\begin{array}{l}\text { Talmapimod } \\
\text { (SCIO-469) }\end{array}$ & p38 $\alpha$ & Rheumatoid arthritis & Phase 2 & $\begin{array}{l}\text { NCT00043732 } \\
\text { NCT00089921 }\end{array}$ \\
\hline VX-702 & $\mathrm{p} 38 \alpha$ & Rheumatoid arthritis & Phase 2 & $\begin{array}{l}\text { NCT00395577 } \\
\text { NCT00205478 }\end{array}$ \\
\hline
\end{tabular}


and that there is therefore a need for more specific inhibitors of each of the p38 group members and more basic research to fully understand how the pathway, especially how each member of the p38 family, is utilized and regulated.

One consequence of the massive pharmaceutical effort over the last 20 years is a large number of very specific, well-tolerated, and readily bioavailable drugs that can enable such basic research. For example, one study using a boutique panel of kinase inhibitors was able to demonstrate that 11 potent and specific p38 inhibitors synergized with Smac-mimetic drugs to kill a subset of AML leukemias, providing the strongest evidence implicating p38 in Smac-mimetic-induced killing ${ }^{179}$. Since several of these p38 inhibitors had already been clinically trialed, this presents an opportunity to fast-track such combinations into the clinic. In our opinion, it is likely that this is where the future of p38 research and p38 inhibitors lies, in revealing the intricate web of inter-connections and inter-dependencies of this core and central regulator of cell stress. We also believe that greater efforts to genetically assess the role of p38 and p38 isoforms in the pathophysiology of inflammatory and other diseases need to be made in order to push forward the clinical application of our burgeoning knowledge.

\section{Acknowledgments}

We thank Peipei Zhang and Ye-hsuan Sun (School of Life Sciences, Xiamen University, China) for their help in preparing this manuscript.
1. Han J, Lee JD, Tobias PS, et al.: Endotoxin induces rapid protein tyrosine phosphorylation in 70Z/3 cells expressing CD14. J Biol Chem. 1993; 268(33): 25009-25014.

PubMed Abstract

2. Han J, Lee JD, Bibbs L, et al:: A MAP kinase targeted by endotoxin and hyperosmolarity in mammalian cells. Science. 1994; 265(5173): 808-811. PubMed Abstract | Publisher Full Text

3. Rouse J, Cohen P, Trigon S, et al:: A novel kinase cascade triggered by stress and heat shock that stimulates MAPKAP kinase-2 and phosphorylation of the small heat shock proteins. Cell. 1994; 78(6): 1027-1037. PubMed Abstract | Publisher Full Text

4. Freshney NW, Rawlinson L, Guesdon F, et al:: Interleukin-1 activates a novel protein kinase cascade that results in the phosphorylation of Hsp27. Cell. 1994; 78(6): 1039-1049.

PubMed Abstract | Publisher Full Text

5. Lee JC, Laydon JT, McDonnell PC, et al:: A protein kinase involved in the regulation of inflammatory cytokine biosynthesis. Nature. 1994; 372(6508): 739-746. PubMed Abstract | Publisher Full Text

6. Jiang $\mathrm{Y}, \mathrm{Chen} \mathrm{C}, \mathrm{Li} Z$, et al: : Characterization of the structure and function of a new mitogen-activated protein kinase (p38beta). J Biol Chem. 1996; 271(30): 17920-17926.

PubMed Abstract | Publisher Full Text

7. Lechner C, Zahalka MA, Giot JF, et al:: ERK6, a mitogen-activated protein kinase involved in C2C12 myoblast differentiation. Proc Natl Acad Sci U S A. 1996; 93(9): 4355-4359.

PubMed Abstract | Publisher Full Text | Free Full Text

8. Li Z, Jiang $Y$, Ulevitch RJ, et al:: The primary structure of $p 38$ gamma: a new member of p38 group of MAP kinases. Biochem Biophys Res Commun. 1996; 228(2): $334-340$.

PubMed Abstract | Publisher Full Text

9. Jiang $\mathrm{Y}, \mathrm{Gram} \mathrm{H}$, Zhao M, et al.: Characterization of the structure and function of the fourth member of p38 group mitogen-activated protein kinases, p38delta. J Biol Chem. 1997; 272(48): 30122-30128. PubMed Abstract | Publisher Full Text

10. Kumar S, McDonnell PC, Gum RJ, et al:: Novel homologues of CSBP/p38 MAP kinase: activation, substrate specificity and sensitivity to inhibition by pyridinyl imidazoles. Biochem Biophys Res Commun. 1997; 235(3): 533-538. PubMed Abstract | Publisher Full Text

11. Raingeaud J, Gupta S, Rogers JS, et al:: Pro-inflammatory cytokines and environmental stress cause $\mathrm{p} 38$ mitogen-activated protein kinase activation by dual phosphorylation on tyrosine and threonine. J Biol Chem. 1995; 270(13): 7420-7426.

PubMed Abstract | Publisher Full Text

12. Lanna A, Gomes DC, Muller-Durovic B, et al:: A sestrin-dependent Erk-Jnk-p38 MAPK activation complex inhibits immunity during aging. Nat Immunol. 2017; 18(3): 354-363.

PubMed Abstract | Publisher Full Text | Free Full Text

13. Obata T, Brown GE, Yaffe MB: MAP kinase pathways activated by stress: the p38 MAPK pathway. Crit Care Med. 2000; 28(4 Suppl): N67-77. PubMed Abstract | Publisher Full Text

14. F Tomas-Loba A, Manieri E, Gonzalez-Teran B, et al.: p38 Is Essential for Cell Cycle Progression and Liver Tumorigenesis. Nature. 2019; 568(7753): 557-560. PubMed Abstract | Publisher Full Text | Faculty Opinions Recommendation
15. Gong X, Liu A, Ming X, et al.: UV-induced interaction between p38 MAPK and p53 serves as a molecular switch in determining cell fate. FEBS Lett. 2010; 584(23): 4711-4716. PubMed Abstract | Publisher Full Text

16. Zauberman A, Zipori D, Krupsky M, et al.: Stress activated protein kinase p38 is involved in IL-6 induced transcriptional activation of STAT3. Oncogene. 1999; 18(26): 3886-3893.

PubMed Abstract | Publisher Full Text

17. Foltz IN, Lee JC, Young PR, et al.: Hemopoietic growth factors with the exception of interleukin-4 activate the p38 mitogen-activated protein kinase pathway. J Biol Chem. 1997; 272(6): 3296-3301.

PubMed Abstract | Publisher Full Text

18. F Salvador JM, Mittelstadt PR, Guszczynski T, et al:: Alternative p38 activation pathway mediated by $\mathrm{T}$ cell receptor-proximal tyrosine kinases. Nat Immunol. 2005; 6(4): 390-395.

PubMed Abstract | Publisher Full Text | Faculty Opinions Recommendation

19. Sun $P$, Yoshizuka N, New $L$, et al.: PRAK is essential for ras-induced senescence and tumor suppression. Cell. 2007: 128(2): 295-308. PubMed Abstract | Publisher Full Text

20. Nagata Y, Takahashi N, Davis RJ, et al.: Activation of p38 MAP kinase and JNK but not ERK is required for erythropoietin-induced erythroid differentiation. Blood. 1998; 92(6): 1859-1869.

PubMed Abstract | Publisher Full Text

21. Zarubin T, Han J: Activation and signaling of the p38 MAP kinase pathway. Cell Res. 2005; 15(1): 11-18.

PubMed Abstract | Publisher Full Text

22. Zheng M, Wang YH, Wu XN, et al.: Inactivation of Rheb by PRAK-mediated phosphorylation is essential for energy-depletion-induced suppression of mTORC1. Nat Cell Biol. 2011; 13(3): 263-272.

PubMed Abstract | Publisher Full Text | Free Full Text

23. Raingeaud J, Whitmarsh AJ, Barrett T, et al:: MKK3- and MKK6-regulated gene expression is mediated by the p38 mitogen-activated protein kinase signal transduction pathway. Mol Cell Biol. 1996; 16(3): 1247-1255. PubMed Abstract | Publisher Full Text | Free Full Text

24. Derijard B, Raingeaud J, Barrett T, et al.: Independent human MAP-kinase signal transduction pathways defined by MEK and MKK isoforms. Science. 1995; 267(5198): 682-685

PubMed Abstract | Publisher Full Tex

25. Han J, Lee JD, Jiang $Y$, et al:: Characterization of the structure and function of a novel MAP kinase kinase (MKK6). J Biol Chem. 1996; 271(6): 2886-2891. PubMed Abstract | Publisher Full Text

26. Enslen H, Raingeaud J, Davis RJ: Selective activation of p38 mitogen-activated protein (MAP) kinase isoforms by the MAP kinase kinases MKK3 and MKK6. $J$ Biol Chem. 1998; 273(3): 1741-1748.

PubMed Abstract | Publisher Full Text

27. Moriguchi T, Kuroyanagi N, Yamaguchi K, et al.: A novel kinase cascade mediated by mitogen-activated protein kinase kinase 6 and MKK3. J Biol Chem. 1996; 271(23): 13675-13679.

PubMed Abstract | Publisher Full Text

28. Ichijo H, Nishida E, Irie K, et al.: Induction of apoptosis by ASK1, a mammalian MAPKKK that activates SAPK/JNK and p38 signaling pathways. Science. 1997; 275(5296): 90-94

PubMed Abstract | Publisher Full Text 
29. Hirai S, Katoh M, Terada M, et al.: MST/MLK2, a member of the mixed lineage kinase family, directly phosphorylates and activates SEK1, an activator of c-Jun N-terminal kinase/stress-activated protein kinase. J Biol Chem. 1997; 272(24): 15167-15173.

PubMed Abstract | Publisher Full Text

30. Takekawa M, Posas F, Saito H: A human homolog of the yeast Ssk2/Ssk22 MAP kinase kinase kinases, MTK1, mediates stress-induced activation of the p38 and JNK pathways. EMBO J. 1997; 16(16): 4973-4982. PubMed Abstract | Publisher Full Text | Free Full Text

31. Bagrodia S, Derijard B, Davis RJ, et al.: Cdc42 and PAK-mediated signaling leads to Jun kinase and p38 mitogen-activated protein kinase activation. J Biol Chem. 1995; 270(47): 27995-27998.

PubMed Abstract | Publisher Full Text

32. Martin GA, Bollag G, McCormick F, et al.: A novel serine kinase activated by rac1/CDC42Hs-dependent autophosphorylation is related to PAK65 and STE20. EMBO J. 1995; 14(9): 1970-1978.

PubMed Abstract | Publisher Full Text | Free Full Text

33. F Ge B, Gram H, Di Padova F, et al.: MAPKK-independent activation of p38alpha mediated by TAB1-dependent autophosphorylation of p38alpha. Science. 2002; 295(5558): 1291-1294.

PubMed Abstract | Publisher Full Text | Faculty Opinions Recommendation

34. F Thapa D, Nichols $C$, Bassi R, et al: TAB1-Induced Autoactivation of p38alpha Mitogen-Activated Protein Kinase Is Crucially Dependent on Threonine 185. Mol Cell Biol. 2018; 38(5): e00409-17. PubMed Abstract | Publisher Full Text | Free Full Text | Faculty Opinions Recommendation

35. Ohkusu-Tsukada $\mathrm{K}$, Tominaga $\mathrm{N}$, Udono $\mathrm{H}$, et al:: Regulation of the maintenance of peripheral T-cell anergy by TAB1-mediated p38 alpha activation. Mol Cell Biol. 2004; 24(16): 6957-6966.

PubMed Abstract | Publisher Full Text | Free Full Text

36. Tanno M, Bassi R, Gorog DA, et al.: Diverse mechanisms of myocardial p38 mitogen-activated protein kinase activation: evidence for MKK-independen activation by a TAB1-associated mechanism contributing to injury during myocardial ischemia. Circ Res. 2003; 93(3): 254-261. PubMed Abstract | Publisher Full Text

37. Mittelstadt PR, Yamaguchi $\mathrm{H}$, Appella $\mathrm{E}$, et al:: T cell receptor-mediated activation of p38\{alpha\} by mono-phosphorylation of the activation loop results in altered substrate specificity. J Biol Chem. 2009; 284(23): 15469-15474. PubMed Abstract | Publisher Full Text | Free Full Text

38. Jirmanova L, Sarma DN, Jankovic D, et al: Genetic disruption of p38alpha Tyr323 phosphorylation prevents T-cell receptor-mediated p38alpha activation and impairs interferon-gamma production. Blood. 2009; 113(10): 2229-2237. PubMed Abstract | Publisher Full Text | Free Full Text

39. F Jirmanova L, Giardino Torchia ML, et al.: Lack of the T cell-specific alternative $\mathrm{p} 38$ activation pathway reduces autoimmunity and inflammation. Blood. 2011; 118(12): 3280-3289.

PubMed Abstract | Publisher Full Text | Free Full Text |

Faculty Opinions Recommendation

40. Alam MS, Gaida MM, Debnath S, et al.: Unique properties of TCR-activated p38 are necessary for NFAT-dependent T-cell activation. PLOS Biol. 2018; 16(1): e2004111.

PubMed Abstract | Publisher Full Text | Free Full Text

41. F Giardino Torchia ML, Dutta D, et al.: Intensity and duration of TCR signaling is limited by $\mathbf{p} 38$ phosphorylation of ZAP- $70^{\text {T293 }}$ and destabilization of the signalosome. Proc Natl Acad Sci U S A. 2018; 115(9): 2174-2179.

PubMed Abstract | Publisher Full Text | Free Full Text |

Faculty Opinions Recommendation

42. Sun $\mathrm{H}$, Charles $\mathrm{CH}$, Lau LF, et al:: MKP-1 (3CH134), an immediate early gene product, is a dual specificity phosphatase that dephosphorylates MAP kinase in vivo. Cell. 1993; 75(3): 487-493.

PubMed Abstract | Publisher Full Text

43. Nunes-Xavier C, Roma-Mateo C, Rios P, et al.: Dual-specificity MAP kinase phosphatases as targets of cancer treatment. Anticancer Agents Med Chem. 2011; 11(1): 109-132.

PubMed Abstract | Publisher Full Text

44. Cho SSL, Han J, James SJ, et al:: Dual-Specificity Phosphatase 12 Targets p38 MAP Kinase to Regulate Macrophage Response to Intracellular Bacterial Infection. Front Immunol. 2017; 8: 1259. PubMed Abstract | Publisher Full Text | Free Full Text

45. Tanoue T, Yamamoto T, Maeda R, et al:: A Novel MAPK phosphatase MKP-7 acts preferentially on JNK/SAPK and p38 alpha and beta MAPKs. J Biol Chem. 2001; 276(28): 26629-26639. PubMed Abstract | Publisher Full Text

46. Manetsch M, Che W, Seidel P, et al.: MKP-1: a negative feedback effector that represses MAPK-mediated pro-inflammatory signaling pathways and cytokine secretion in human airway smooth muscle cells. Cell Signal. 2012; 24(4): 907-913. PubMed Abstract | Publisher Full Text

47. Topolska-Wos AM, Rosinska S, Filipek A: MAP kinase p38 is a novel target of CacyBP/SIP phosphatase. Amino Acids. 2017; 49(6): 1069-1076. PubMed Abstract | Publisher Full Text | Free Full Text

48. Liu G, Hu X, Sun B, et al:: Phosphatase Wip1 negatively regulates neutrophil development through p38 MAPK-STAT1. Blood. 2013; 121(3): 519-529. PubMed Abstract | Publisher Full Text
49. Takekawa M, Maeda T, Saito H: Protein phosphatase 2Calpha inhibits the human stress-responsive p38 and JNK MAPK pathways. EMBO J. 1998; 17(16): 4744-4752.

PubMed Abstract | Publisher Full Text | Free Full Text

50. Maeda T, Wurgler-Murphy SM, Saito H: A two-component system that regulates an osmosensing MAP kinase cascade in yeast. Nature. 1994; 369(6477): 242-245. PubMed Abstract | Publisher Full Text

51. Qi X, Pohl NM, Loesch M, et al.: p38alpha antagonizes p38gamma activity through c-Jun-dependent ubiquitin-proteasome pathways in regulating Ras transformation and stress response. J Biol Chem. 2007; 282(43): 31398-31408. PubMed Abstract | Publisher Full Text

52. F Chen YW, Ko WC, Chen CS, et al:: RIOK-1 Is a Suppressor of the p38 MAPK Innate Immune Pathway in Caenorhabditis elegans. Front Immunol. 2018; 9: 774. PubMed Abstract | Publisher Full Text | Free Full Text | Faculty Opinions Recommendation

53. Bird TA, Schule HD, Delaney $P$, et al.: The interleukin-1-stimulated protein kinase that phosphorylates heat shock protein hsp27 is activated by MAP kinase. FEBS Lett. 1994; 338(1): 31-36.

PubMed Abstract | Publisher Full Text

54. McLaughlin MM, Kumar S, McDonnell PC, et al.: Identification of mitogenactivated protein (MAP) kinase-activated protein kinase-3, a novel substrate of CSBP p38 MAP kinase. J Biol Chem. 1996; 271(14): 8488-8492. PubMed Abstract | Publisher Full Text

55. New $L$, Jiang $Y$, Zhao M, et al.: PRAK, a novel protein kinase regulated by the p38 MAP kinase. EMBO J. 1998; 17(12): 3372-3384. PubMed Abstract | Publisher Full Text | Free Full Text

56. Deak M, Clifton AD, Lucocq LM, et al: Mitogen- and stress-activated protein kinase-1 (MSK1) is directly activated by MAPK and SAPK2/p38, and may mediate activation of CREB. EMBO J. 1998; 17(15): 4426-4441. PubMed Abstract | Publisher Full Text | Free Full Text

57. Waskiewicz AJ, Flynn A, Proud CG, et al.: Mitogen-activated protein kinases activate the serine/threonine kinases Mnk1 and Mnk2. EMBO J. 1997; 16(8): 1909-1920.

PubMed Abstract | Publisher Full Text | Free Full Text

58. Fukunaga R, Hunter T: MNK1, a new MAP kinase-activated protein kinase, isolated by a novel expression screening method for identifying protein kinase substrates. EMBO J. 1997; 16(8): 1921-1933. PubMed Abstract | Publisher Full Text | Free Full Text

59. F Thornton TM, Pedraza-Alva G, Deng B, et al:: Phosphorylation by p38 MAPK as an alternative pathway for GSK3beta inactivation. Science. 2008; 320(5876): $667-670$

PubMed Abstract | Publisher Full Text | Free Full Text |

Faculty Opinions Recommendation

60. Bikkavilli RK, Feigin ME, Malbon CC: p38 mitogen-activated protein kinase regulates canonical Wnt-beta-catenin signaling by inactivation of GSK3beta. J Cell Sci. 2008; 121(Pt 21): 3598-3607.

PubMed Abstract | Publisher Full Tex

61. F Sumara G, Formentini I, Collins S, et al:: Regulation of PKD by the MAPK p38delta in insulin secretion and glucose homeostasis. Cell. 2009; 136(2): 235-248.

PubMed Abstract | Publisher Full Text | Free Full Text |

Faculty Opinions Recommendation

62. Han J, Jiang Y, Li Z, et al:: Activation of the transcription factor MEF2C by the MAP kinase p38 in inflammation. Nature. 1997; 386(6622): 296-299. PubMed Abstract | Publisher Full Text

63. Tan $\mathrm{Y}$, Rouse J, Zhang A, et al.: FGF and stress regulate CREB and ATF-1 via a pathway involving p38 MAP kinase and MAPKAP kinase-2. EMBO J. 1996; 15(17): 4629-4642. PubMed Abstract | Free Full Text

64. Barsyte-Lovejoy D, Galanis A, Sharrocks AD: Specificity determinants in MAPK signaling to transcription factors. J Biol Chem. 2002; 277(12): 9896-9903. PubMed Abstract | Publisher Full Text

65. Hazzalin CA, Cano E, Cuenda A, et al:: p38/RK is essential for stress-induced nuclear responses: JNK/SAPKs and c-Jun/ATF-2 phosphorylation are insufficient. Curr Biol. 1996; 6(8): 1028-1031.

PubMed Abstract | Publisher Full Text

66. Whitmarsh AJ, Yang SH, Su MS, et al:: Role of p38 and JNK mitogen-activated protein kinases in the activation of ternary complex factors. Mol Cell Biol. 1997; 17(5): 2360-2371.

PubMed Abstract | Publisher Full Text | Free Full Text

67. Janknecht $\mathrm{R}$, Hunter $\mathrm{T}$ : Convergence of MAP kinase pathways on the ternary complex factor Sap-1a. EMBO J. 1997; 16(7): 1620-1627. PubMed Abstract | Publisher Full Text | Free Full Text

68. Wang $X Z$, Ron D: Stress-induced phosphorylation and activation of the transcription factor CHOP (GADD153) by p38 MAP Kinase. Science. 1996; 272(5266): 1347-1349.

PubMed Abstract | Publisher Full Text

69. Bulavin DV, Saito S, Hollander MC, et al.: Phosphorylation of human p53 by p38 kinase coordinates $\mathrm{N}$-terminal phosphorylation and apoptosis in response to UV radiation. EMBO J. 1999; 18(23): 6845-6854. PubMed Abstract | Publisher Full Text | Free Full Text

70. Huang C, Ma WY, Maxiner A, et al:: p38 kinase mediates UV-induced 
phosphorylation of p53 protein at serine 389. J Biol Chem. 1999; 274(18): 12229-12235.

PubMed Abstract | Publisher Full Text

71. Galibert MD, Carreira S, Goding CR: The Usf-1 transcription factor is a novel target for the stress-responsive p38 kinase and mediates UV-induced Tyrosinase expression. EMBO J. 2001; 20(17): 5022-5031.

PubMed Abstract | Publisher Full Text | Free Full Text

72. Gomez del Arco P, Martinez-Martinez S, Maldonado JL, et al:: A role for the p38 MAP kinase pathway in the nuclear shuttling of NFATp. J Biol Chem. 2000; 275(18): 13872-13878

PubMed Abstract | Publisher Full Tex

73. F Rampalli S, Li L, Mak E, et al:: p38 MAPK signaling regulates recruitment of Ash2L-containing methyltransferase complexes to specific genes during differentiation. Nat Struct Mol Biol. 2007; 14(12): 1150-1156.

PubMed Abstract | Publisher Full Text | Free Full Text |

Faculty Opinions Recommendation

74. Ramsauer K, Sadzak I, Porras A, et al:: p38 MAPK enhances STAT1-dependent transcription independently of Ser-727 phosphorylation. Proc Natl Acad Sci U S A. 2002; 99(20): 12859-12864

PubMed Abstract | Publisher Full Text | Free Full Text

75. F Lee J, Sun C, Zhou Y, et al.: p38 MAPK-mediated regulation of Xbp1s is crucial for glucose homeostasis. Nat Med. 2011; 17(10): 1251-1260.

PubMed Abstract | Publisher Full Text | Free Full Text |

Faculty Opinions Recommendation

76. Lin KC, Moroishi T, Meng Z, et al.: Regulation of Hippo pathway transcription factor TEAD by p38 MAPK-induced cytoplasmic translocation. Nat Cell Biol. 2017; 19(8): 996-1002.

PubMed Abstract | Publisher Full Text | Free Full Text

77. Pierrat B, Correia JS, Mary JL, et al:: RSK-B, a novel ribosomal S6 kinase family member, is a CREB kinase under dominant control of p38alpha mitogen-activated protein kinase (p38alphaMAPK). J Biol Chem. 1998; 273(45): 29661-29671. PubMed Abstract | Publisher Full Text

78. Kaur R, Liu X, Gjoerup O, et al:: Activation of p21-activated kinase 6 by MAP kinase kinase 6 and p38 MAP kinase. J Biol Chem. 2005; 280(5): 3323-3330. PubMed Abstract | Publisher Full Text

79. Jones DR, Bultsma Y, Keune WJ, et al.: Nuclear Ptdlns5P as a transducer of stress signaling: an in vivo role for PIP4Kbeta. Mol Cell. 2006; 23(5): 685-695. PubMed Abstract | Publisher Full Text

80. F Saurin AT, Durgan J, Cameron AJ, et al:: The regulated assembly of a PKCepsilon complex controls the completion of cytokinesis. Nat Cell Biol. 2008; 10(8): 891-901.

PubMed Abstract | Publisher Full Text | Faculty Opinions Recommendation

81. Cuenda A, Cohen P, Buee-Scherrer V, et al:: Activation of stress-activated protein kinase-3 (SAPK3) by cytokines and cellular stresses is mediated via SAPKK3 (MKK6); comparison of the specificities of SAPK3 and SAPK2 (RK p38). EMBO J. 1997; 16(2): 295-305 PubMed Abstract | Publisher Full Text | Free Full Text

82. Qiao L, MacDougald OA, Shao J: CCAAT/enhancer-binding protein alpha mediates induction of hepatic phosphoenolpyruvate carboxykinase by p38 mitogen-activated protein kinase. J Biol Chem. 2006; 281(34): 24390-24397. PublMed Abstract | Publisher Full Tex

83. Engelman JA, Lisanti MP, Scherer PE: Specific inhibitors of p38 mitogenactivated protein kinase block 3T3-L1 adipogenesis. J Biol Chem. 1998; 273(48): 32111-32120.

PubMed Abstract | Publisher Full Text

84. Williamson EA, Williamson IK, Chumakov AM, et al.: CCAAT/enhancer binding protein epsilon: changes in function upon phosphorylation by p38 MAP kinase. Blood. 2005; 105(10): 3841-3847. PubMed Abstract | Publisher Full Text | Free Full Text

85. Morillo SM, Abanto EP, Roman MJ, et al.: Nerve growth factor-induced cell cycle reentry in newborn neurons is triggered by P38 $^{\text {MAPK }}$-dependent E2F4 phosphorylation. Mol Cell Biol. 2012; 32(14): 2722-2737. PubMed Abstract | Publisher Full Text | Free Full Text

86. Lee H, Bai W: Regulation of estrogen receptor nuclear export by ligandinduced and p38-mediated receptor phosphorylation. Mol Cell Biol. 2002; 22(16): 5835-5845.

PubMed Abstract | Publisher Full Text | Free Full Text

87. Tanos T, Marinissen MJ, Leskow FC, et al:: Phosphorylation of c-Fos by members of the p38 MAPK family. Role in the AP-1 response to UV light. $J$ Bio Chem. 2005; 280(19): 18842-18852.

PubMed Abstract | Publisher Full Text

88. Ho KK, McGuire VA, Koo CY, et al:: Phosphorylation of FOXO3a on Ser-7 by p38 promotes its nuclear localization in response to doxorubicin. $J$ Biol Chem. 2012; 287(2): 1545-1555.

PubMed Abstract | Publisher Full Text | Free Full Text

89. Miller AL, Webb MS, Copik AJ, et al:: p38 Mitogen-activated protein kinase (MAPK) is a key mediator in glucocorticoid-induced apoptosis of lymphoid cells: correlation between p38 MAPK activation and site-specific phosphorylation of the human glucocorticoid receptor at serine 211 . $\mathrm{Mol}$ Endocrinol. 2005; 19(6): 1569-1583. PubMed Abstract | Publisher Full Text

90. Macfarlane WM, Smith SB, James RF, et al:: The p38/reactivating kinase mitogen-activated protein kinase cascade mediates the activation of the transcription factor insulin upstream factor 1 and insulin gene transcription by high glucose in pancreatic beta-cells. J Biol Chem. 1997; 272(33): 20936-20944. PubMed Abstract | Publisher Full Text

91. Katz S, Aronheim A: Differential targeting of the stress mitogen-activated protein kinases to the c-Jun dimerization protein 2. Biochem J. 2002; 368(Pt 3): 939-945.

PubMed Abstract | Publisher Full Text | Free Full Text

92. Humar M, Loop T, Schmidt R, et al.: The mitogen-activated protein kinase $\mathrm{p} 38$ regulates activator protein 1 by direct phosphorylation of c-Jun. Int $J$ Biochem Cell Biol. 2007; 39(12): 2278-2288.

PubMed Abstract | Publisher Full Text

93. Sii-Felice K, Pouponnot $C$, Gillet $S$, et al: MafA transcription factor is phosphorylated by p38 MAP kinase. FEBS Lett. 2005; 579(17): 3547-3554. PubMed Abstract | Publisher Full Text

94. Zhao M, New L, Kravchenko VV, et al.: Regulation of the MEF2 family of transcription factors by p38. Mol Cell Biol. 1999; 19(1): 21-30. PubMed Abstract | Publisher Full Text | Free Full Text

95. Mansky KC, Sankar U, Han J, et al:: Microphthalmia transcription factor is a target of the p38 MAPK pathway in response to receptor activator of NF-kappa B ligand signaling. J Biol Chem. 2002; 277(13): 11077-11083. PubMed Abstract | Publisher Full Text

96. Suelves M, Lluis F, Ruiz V, et al.: Phosphorylation of MRF4 transactivation domain by $\mathrm{p} 38$ mediates repression of specific myogenic genes. $E M B O \mathrm{~J}$. 2004; 23(2): 365-375.

PubMed Abstract | Publisher Full Text | Free Full Text

97. Matsumoto M, Kogawa M, Wada S, et al.: Essential role of p38 mitogen-activated protein kinase in cathepsin $\mathrm{K}$ gene expression during osteoclastogenesis through association of NFATc1 and PU.1. J Biol Chem. 2004; 279(44): 45969-45979.

PubMed Abstract | Publisher Full Text

98. Yang TT, Xiong Q, Enslen $\mathrm{H}$, et al.: Phosphorylation of NFATc4 by p38 mitogenactivated protein kinases. Mol Cell Biol. 2002; 22(11): 3892-3904.

PubMed Abstract | Publisher Full Text | Free Full Text

99. Sekine $\mathrm{Y}$, Takagahara S, Hatanaka R, et al:: p38 MAPKs regulate the expression of genes in the dopamine synthesis pathway through phosphorylation of NR4A nuclear receptors. J Cell Sci. 2011; 124(Pt 17): 3006-3016.

PubMed Abstract | Publisher Full Text

100. Li L, Liu Y, Chen HZ, et al.: Impeding the interaction between Nur77 and p38 reduces LPS-induced inflammation. Nat Chem Biol. 2015; 11(5): 339-346. PubMed Abstract | Publisher Full Text

101. Ortuno MJ, Ruiz-Gaspa S, Rodriguez-Carballo $\mathrm{E}$, et al: $\mathrm{p} 38$ regulates expression of osteoblast-specific genes by phosphorylation of osterix. J Biol Chem. 2010; 285(42): 31985-31994.

PubMed Abstract | Publisher Full Text | Free Full Text

102. Mikkola I, Bruun JA, Bjorkoy G, et al:: Phosphorylation of the transactivation domain of Pax 6 by extracellular signal-regulated kinase and p38 mitogenactivated protein kinase. J Biol Chem. 1999; 274(21): 15115-15126. PubMed Abstract | Publisher Full Text

103. Barger PM, Browning AC, Garner AN, et al:: p38 mitogen-activated protein kinase activates peroxisome proliferator-activated receptor alpha: a potential role in the cardiac metabolic stress response. J Biol Chem. 2001; 276(48): 44495-44501.

PubMed Abstract | Publisher Full Text

104. Hayes SA, Huang X, Kambhampati S, et al:: p38 MAP kinase modulates Smaddependent changes in human prostate cell adhesion. Oncogene. 2003; 22(31): 4841-4850.

PubMed Abstract | Publisher Full Text

105. Ryu KJ, Park SM, Park SH, et al.: p38 Stabilizes Snail by Suppressing DYRK2 Mediated Phosphorylation That Is Required for GSK3beta-betaTrCP-Induced Snail Degradation. Cancer Res. 2019; 79(16): 4135-4148. PubMed Abstract | Publisher Full Text

106. Kovarik P, Stoiber D, Eyers PA, et al:: Stress-induced phosphorylation of STAT1 at Ser727 requires $\mathbf{p} 38$ mitogen-activated protein kinase whereas IFN-gamma uses a different signaling pathway. Proc Natl Acad Sci U S A. 1999; 96(24) 13956-61.

PubMed Abstract | Publisher Full Text | Free Full Text

107. Visconti R, Gadina M, Chiariello M, et al:: Importance of the MKK6/p38 pathway for interleukin-12-induced STAT4 serine phosphorylation and transcriptional activity. Blood. 2000; 96(5): 1844-52. PubMed Abstract

108. Hong J, Zhou J, Fu J, et al:: Phosphorylation of serine 68 of Twist1 by MAPKs stabilizes Twist1 protein and promotes breast cancer cell invasiveness. Cancer Res. 2011; 71(11): 3980-90. PubMed Abstract | Publisher Full Text | Free Full Tex

109. F Simone C, Forcales SV, Hill DA, et al:: p38 pathway targets SWI-SNF chromatin-remodeling complex to muscle-specific loci. Nat Genet. 2004; 36(7): $738-43$.

PubMed Abstract | Publisher Full Text | Faculty Opinions Recommendation

110. Forcales SV, Albini S, Giordani L, et al:: Signal-dependent incorporation of MyoD-BAF60c into Brg1-based SWI/SNF chromatin-remodelling complex. EMBO J. 2012; 31(2): 301-16.

PubMed Abstract | Publisher Full Text | Free Full Text

111. Anwar T, Arellano-Garcia C, Ropa J, et al.: p38-mediated phosphorylation 
at T367 induces EZH2 cytoplasmic localization to promote breast cancer metastasis. Nat Commun. 2018; 9(1): 2801.

PubMed Abstract | Publisher Full Text | Free Full Text

112. F Seong KH, Li D, Shimizu H, et al:: Inheritance of stress-induced, ATF-2 dependent epigenetic change. Cell. 2011; 145(7): 1049-1061. PubMed Abstract | Publisher Full Text | Faculty Opinions Recommendation

113. Wu XN, Wang XK, Wu SQ, et al:: Phosphorylation of Raptor by p38beta participates in arsenite-induced mammalian target of rapamycin complex 1 (mTORC1) activation. J Biol Chem. 2011; 286(36): 31501-31511. PubMed Abstract | Publisher Full Text | Free Full Text

114. F Gonzalez-Teran B, Lopez JA, Rodriguez E, et al:: p38gamma and delta promote heart hypertrophy by targeting the mTOR-inhibitory protein DEPTOR for degradation. Nat Commun. 2016; 7: 10477.

PubMed Abstract | Publisher Full Text | Free Full Text | Faculty Opinions Recommendation

115. Zheng $\mathrm{H}$, Seit-Nebi A, Han X, et al.: A posttranslational modification cascade involving P38, Tip60, and PRAK mediates oncogene-induced senescence. Mol Cell. 2013: 50(5): 699-710.

PubMed Abstract | Publisher Full Text | Free Full Text

116. Xu Y, Liao R, Li N, et al.: Phosphorylation of Tip60 by p38alpha regulates p53-mediated PUMA induction and apoptosis in response to DNA damage. Oncotarget 2014: 5(24): 12555-12572. PubMed Abstract | Publisher Full Text | Free Full Text

117. Li W, Zhu J, Dou J, et al:: Phosphorylation of LAMP2A by p38 MAPK couples ER stress to chaperone-mediated autophagy. Nat Commun. 2017; 8(1): 1763. PubMed Abstract | Publisher Full Text | Free Full Text

118. Allen M, Svensson L, Roach M, et al.: Deficiency of the stress kinase p38alpha results in embryonic lethality: characterization of the kinase dependence of stress responses of enzyme-deficient embryonic stem cells. J Exp Med. 2000; 191(5): 859-870.

PubMed Abstract | Publisher Full Text | Free Full Text

119. Tamura K, Sudo T, Senftleben U, et al.: Requirement for p38alpha in erythropoietin expression: a role for stress kinases in erythropoiesis. Cell. 2000; 102(2): 221-231. PubMed Abstract | Publisher Full Text

120. Adams RH, Porras A, Alonso G, et al.: Essential role of p38alpha MAP kinase in placental but not embryonic cardiovascular development. Mol Cell. 2000; 6(1) 109-116.

PubMed Abstract | Publisher Full Text

121. Mudgett JS, Ding J, Guh-Siesel L, et al.: Essential role for p38alpha mitogenactivated protein kinase in placental angiogenesis. Proc Natl Acad Sci U S A. 2000; 97(19): 10454-10459.

PubMed Abstract | Publisher Full Text | Free Full Text

122. Wong ES, Le Guezennec X, Demidov ON, et al:: p38MAPK controls expression of multiple cell cycle inhibitors and islet proliferation with advancing age. Dev Cell. 2009; 17(1): 142-149.

PubMed Abstract | Publisher Full Text

123. Brichkina A, Bertero T, Loh HM, et al:: p38MAPK builds a hyaluronan cancer niche to drive lung tumorigenesis. Genes Dev. 2016; 30(23): 2623-2636. PubMed Abstract | Publisher Full Text | Free Full Text

124. Rao PS, Satelli A, Zhang S, et al.: RNF2 is the target for phosphorylation by the p38 MAPK and ERK signaling pathways. Proteomics. 2009; 9(10): 2776-2787. PubMed Abstract | Publisher Full Text | Free Full Text

125. Ma H, Liu Z, Zhong CQ, et al:: Inactivation of Cyclic AMP Response Element Transcription Caused by Constitutive p38 Activation Is Mediated by Hyperphosphorylation-Dependent CRTC2 Nucleocytoplasmic Transport. Mol Cell Biol. 2019; 39(9): e00554-18.

PubMed Abstract | Publisher Full Text | Free Full Text

126. Page JL, Wang X, Sordillo LM, et al:: MEKK1 signaling through $p 38$ leads to transcriptional inactivation of E47 and repression of skeletal myogenesis. J Biol Chem. 2004; 279(30): 30966-30972. PubMed Abstract | Publisher Full Text

127. Lluis F, Ballestar E, Suelves M, et al.: E47 phosphorylation by p38 MAPK promotes MyoD/E47 association and muscle-specific gene transcription. EMBO J. 2005; 24(5): 974-84.

PubMed Abstract | Publisher Full Text | Free Full Text

128. Xiu M, Kim J, Sampson E, et al: The transcriptional repressor HBP1 is a target of the p38 mitogen-activated protein kinase pathway in cell cycle regulation. Mol Cell Biol. 2003; 23(23): 8890-901.

PubMed Abstract | Publisher Full Text | Free Full Text

129. Cuadrado A, Lafarga V, Cheung PCF, et al:: A new p38 MAP kinase-regulated transcriptional coactivator that stimulates p53-dependent apoptosis. EMBO 2007; 26(8): 2115-26.

PubMed Abstract | Publisher Full Text | Free Full Text

130 Puigserver $\mathrm{P}$, Rhee $\mathrm{J}$, Lin J, et al.: Cytokine stimulation of energy expenditure through p38 MAP kinase activation of PPARgamma coactivator-1. Mol Cell. 2001; 8(5): 971-82. PubMed Abstract | Publisher Full Text

131. Delston RB, Matatall KA, Sun Y, et al:: p38 phosphorylates Rb on Ser567 by a novel, cell cycle-independent mechanism that triggers Rb-Hdm2 interaction and apoptosis. Oncogene. 2011; 30(5): 588-99. PubMed Abstract | Publisher Full Text | Free Full Text

132. Gianni M, Parrella E, Raska I Jr, et al.: P38MAPK-dependent phosphorylation and degradation of SRC-3/AIB1 and RARalpha-mediated transcription. EMBO J. 2006; 25(4): 739-75

PubMed Abstract | Publisher Full Text | Free Full Text

133. Goloudina A, Yamaguchi H, Chervyakova DB, et al.: Regulation of human Cdc25A stability by Serine 75 phosphorylation is not sufficient to activate a $S$ phase checkpoint. Cell Cycle. 2003; 2(5): 473-478.

PubMed Abstract | Publisher Full Text

134. Lemaire M, Froment $\mathrm{C}$, Boutros R, et al:: CDC25B phosphorylation by $\mathrm{p} 38$ and MK-2. Cell Cycle. 2006; 5(15): 1649-1653. PubMed Abstract | Publisher Full Text

135. Casanovas O, Miro F, Estanyol JM, et al.: Osmotic stress regulates the stability of cyclin D1 in a p38SAPK2-dependent manner. J Biol Chem. 2000; 275(45): 35091-35097.

PubMed Abstract | Publisher Full Text

136. Casanovas $\mathrm{O}$, Jaumot $\mathrm{M}$, Paules $\mathrm{AB}$, et al:: P38SAPK2 phosphorylates cyclin D3 at Thr-283 and targets it for proteasomal degradation. Oncogene. 2004; 23(45): $7537-7544$

PubMed Abstract | Publisher Full Text

137. Joaquin M, Gubern A, Gonzalez-Nunez D, et al.: The p57 CDKi integrates stress signals into cell-cycle progression to promote cell survival upon stress. $E M B O$ J. 2012; 31(13): 2952-64. PubMed Abstract | Publisher Full Text | Free Full Text

138. Min H, Ghatnekar GS, Ghatnekar AV, et al:: 2-Methoxyestradiol induced Bax phosphorylation and apoptosis in human retinoblastoma cells via p38 MAPK activation. Mol Carcinog. 2012; 51(7): 576-85.

PubMed Abstract | Publisher Full Text

139. Cai B, Chang SH, Becker EBE, et al:: p38 MAP kinase mediates apoptosis through phosphorylation of BimEL at Ser-65. J Biol Chem. 2006; 281(35): 25215-22. PubMed Abstract | Publisher Full Text

140. Alvarado-Kristensson M, Melander F, Leandersson K, et al.: p38-MAPK signals survival by phosphorylation of caspase-8 and caspase- 3 in human neutrophils. J Exp Med. 2004; 199(4): 449-58.

PubMed Abstract | Publisher Full Text | Free Full Text

141. Seifert A, Clarke PR: p38alpha- and DYRK1A-dependent phosphorylation of caspase-9 at an inhibitory site in response to hyperosmotic stress. Cell Signal. 2009; 21(11): 1626-33.

PubMed Abstract | Publisher Full Text

142. Chandrasekaran S, Tan TX, Hall JR, et al:: Stress-stimulated mitogen-activated protein kinases control the stability and activity of the Cdt1 DNA replication licensing factor. Mol Cell Biol. 2011; 31(22): 4405-16. PubMed Abstract | Publisher Full Text | Free Full Text

143. Yang Q, Li W, She H, et al.: Stress induces p38 MAPK-mediated phosphorylation and inhibition of Drosha-dependent cell survival. Mol Cell. 2015; 57(4): 721-734

PubMed Abstract | Publisher Full Text | Free Full Text

144. Danckwardt S, Gantzert AS, Macher-Goeppinger S, et al.: p38 MAPK controls prothrombin expression by regulated RNA 3' end processing. Mol Cell. 2011; 41(3): 298-310

PubMed Abstract | Publisher Full Text

145. Lu C, Shi Y, Wang Z, et al: Serum starvation induces H2AX phosphorylation to regulate apoptosis via p38 MAPK pathway. FEBS Lett. 2008; 582(18): 2703-8. PubMed Abstract | Publisher Full Text

146. Zhong SP, Ma WY, Dong Z: ERKs and p38 kinases mediate ultraviolet Binduced phosphorylation of histone $\mathrm{H} 3$ at serine 10. J Biol Chem. 2000; 275(28): 20980-4.

PubMed Abstract | Publisher Full Text

147. Lafarga V, Cuadrado A, Lopez de Silanes I, et al:: p38 Mitogen-activated protein kinase- and HuR-dependent stabilization of p21 ${ }^{\text {cip1 }}$ mRNA mediates the $G_{1} / S$ checkpoint. Mol Cell Biol. 2009; 29(16): 4341-4351. PubMed Abstract | Publisher Full Text | Free Full Text

148. Briata $\mathrm{P}$, Forcales SV, Ponassi M, et al:: p38-dependent phosphorylation of the mRNA decay-promoting factor KSRP controls the stability of select myogenic transcripts. Mol Cell. 2005; 20(6): 891-903. PubMed Abstract | Publisher Full Text

149. Knight JD, Tian R, Lee RE, et al.: A novel whole-cell lysate kinase assay identifies substrates of the p38 MAPK in differentiating myoblasts. Skelet Muscle. 2012; 2: 5

PubMed Abstract | Publisher Full Text | Free Full Text

150. Al-Ayoubi AM, Zheng $\mathrm{H}$, Liu Y, et al:: Mitogen-activated protein kinase phosphorylation of splicing factor 45 (SPF45) regulates SPF45 alternative splicing site utilization, proliferation, and cell adhesion. Mol Cell Biol. 2012; 32(14): 2880-2893

PubMed Abstract | Publisher Full Text | Free Full Text

151. Mace G, Miaczynska M, Zerial M, et al.: Phosphorylation of EEA1 by p38 MAP kinase regulates mu opioid receptor endocytosis. EMBO J. 2005; 24(18): 3235-3246.

PubMed Abstract | Publisher Full Text | Free Full Text

152. Cavalli V, Vilbois $\mathrm{F}$, Corti $\mathrm{M}$, et al.: The stress-induced MAP kinase $\mathrm{p} 38$ regulates endocytic trafficking via the GDI:Rab5 complex. Mol Cell. 2001; 7(2): 421-432. PubMed Abstract | Publisher Full Text

153. Kelkar N, Standen CL, Davis RJ: Role of the JIP4 scaffold protein in the regulation of mitogen-activated protein kinase signaling pathways. Mol Cell Biol. 2005; 25(7): 2733-2743.

PubMed Abstract | Publisher Full Text | Free Full Text 
154. Cheung PC, Campbell DG, Nebreda AR, et al:: Feedback control of the protein kinase TAK1 by SAPK2a/p38alpha. EMBO J. 2003; 22(21): 5793-5805. PubMed Abstract | Publisher Full Text | Free Full Text

155. Mendoza H, Campbell DG, Burness K, et al.: Roles for TAB1 in regulating the IL-1-dependent phosphorylation of the TAB3 regulatory subunit and activity of the TAK1 complex. Biochem J. 2008; 409(3): 711-722. PubMed Abstract | Publisher Full Text

156. Zakrzewska M, Opalinski L, Haugsten EM, et al.: Crosstalk between p38 and Erk 1/2 in Downregulation of FGF1-Induced Signaling. Int J Mol Sci. 2019; 20(8): 1826. PubMed Abstract | Publisher Full Text | Free Full Text

157. Winograd-Katz SE, Levitzki A: Cisplatin induces PKB/Akt activation and p38 MAPK $^{\text {Ma }}$ phosphorylation of the EGF receptor. Oncogene. 2006; 25(56): 7381-7390. PubMed Abstract | Publisher Full Text

158. Sørensen V, Zhen Y, Zakrzewska M, et al:: Phosphorylation of fibroblast growth factor (FGF) receptor 1 at Ser777 by p38 mitogen-activated protein kinase regulates translocation of exogenous FGF1 to the cytosol and nucleus. Mol Cell Biol. 2008; 28(12): 4129-4141. PubMed Abstract | Publisher Full Text | Free Full Text

159. Gasser A, Cheng X, Gilmore ES, et al:: Two Nedd4-binding motifs underlie modulation of sodium channel $\mathrm{Na}_{v} 1.6$ by p38 MAPK. J Biol Chem. 2010; 285(34): 26149-26161.

PubMed Abstract | Publisher Full Text | Free Full Text

160. Khaled AR, Moor AN, Li A, et al:: Trophic factor withdrawal: p38 mitogenactivated protein kinase activates NHE1, which induces intracellular alkalinization. Mol Cell Biol. 2001; 21(22): 7545-7557. PubMed Abstract | Publisher Full Text | Free Full Text

161. Börsch-Haubold AG, Bartoli F, Asselin J, et al:: Identification of the phosphorylation sites of cytosolic phospholipase A2 in agonist-stimulated human platelets and HeLa cells. J Biol Chem. 1998; 273(8): 4449-4458. PubMed Abstract | Publisher Full Text

162. F Xu P, Derynck R: Direct activation of TACE-mediated ectodomain shedding by p38 MAP kinase regulates EGF receptor-dependent cell proliferation. $\mathrm{Mol}$ Cell. 2010; 37(4): 551-566.

PubMed Abstract | Publisher Full Text | Free Full Text Faculty Opinions Recommendation

163. Hedges JC, Yamboliev IA, Ngo M, et al:: p38 mitogen-activated protein kinase expression and activation in smooth muscle. Am J Physiol. 1998; 275(2): C527-534.

PubMed Abstract | Publisher Full Text

164. Ku NO, Azhar S, Omary MB: Keratin 8 phosphorylation by p38 kinase regulates cellular keratin filament reorganization: modulation by a keratin 1-like disease causing mutation. J Biol Chem. 2002; 277(13): 10775-10782. PubMed Abstract | Publisher Full Text

165. Barascu A, Le Chalony C, Pennarun G, et al: Oxidative stress induces an ATMindependent senescence pathway through p38 MAPK-mediated lamin B1 accumulation. EMBO J. 2012; 31(5): 1080-1094. PubMed Abstract | Publisher Full Text | Free Full Text

166. Huang $\mathrm{C}$, Borchers $\mathrm{CH}$, Schaller $\mathrm{MD}$, et al.: Phosphorylation of paxillin by P38MAPK is involved in the neurite extension of PC-12 cells. J Cell Biol. 2004; 164(4): 593-602. PubMed Abstract | Publisher Full Text | Free Full Text

167. Parker CG, Hunt J, Diener K, et al.: Identification of stathmin as a novel substrate for p38 delta. Biochem Biophys Res Commun. 1998; 249(3): 791-796. PubMed Abstract | Publisher Full Text

168. F Sabio G, Arthur JS, Kuma Y, et al:: p38gamma regulates the localisation of SAP97 in the cytoskeleton by modulating its interaction with GKAP. EMBO J. 2005; 24(6): 1134-1145.

PubMed Abstract | Publisher Full Text | Free Full Text Faculty Opinions Recommendation

169. Reynolds $\mathrm{CH}$, Nebreda AR, Gibb GM, et al:: Reactivating kinase/p38 phosphorylates tau protein in vitro. J Neurochem. 1997; 69(1): 191-198. PubMed Abstract | Publisher Full Text

170. Ittner A, Chua SW, Bertz J, et al:: Site-specific phosphorylation of tau inhibits amyloid- $\beta$ toxicity in Alzheimer's mice. Science. 2016; 354(6314): 904-908. PubMed Abstract | Publisher Full Text

171. Hall EH, Balsbaugh JL, Rose KL, et al.: Comprehensive analysis of phosphorylation sites in Tensin1 reveals regulation by p38MAPK. Mol Cell Proteomics. 2010; 9(12): 2853-2863. PubMed Abstract | Publisher Full Text | Free Full Text

172. Kuma $Y$, Campbell DG, Cuenda A: Identification of glycogen synthase as a new substrate for stress-activated protein kinase 2b/p38beta. Biochem J. 2004; 379(Pt 1): 133-139.

PubMed Abstract | Publisher Full Text | Free Full Text

173. Chen J, Ren Y, Gui C, et al.: Phosphorylation of Parkin at serine 131 by p38 MAPK promotes mitochondrial dysfunction and neuronal death in mutant A53T $\alpha$-synuclein model of Parkinson's disease. Cell Death Dis. 2018; 9(6): 700 . PubMed Abstract | Publisher Full Text | Free Full Text

174. Makni-Maalej K, Boussetta T, Hurtado-Nedelec M, et al.: The TLR7/8 agonist CL097 primes $\mathrm{N}$-formyl-methionyl-leucyl-phenylalanine-stimulated NADPH oxidase activation in human neutrophils: critical role of p47phox phosphorylation and the proline isomerase Pin1. J Immunol. 2012; 189(9): 4657-4665.

PubMed Abstract | Publisher Full Text
175. Linares JF, Duran A, Reina-Campos M, et al:: Amino Acid Activation of mTORC by a PB1-Domain-Driven Kinase Complex Cascade. Cell Rep. 2015; 12(8): 1339-1352.

PubMed Abstract | Publisher Full Text | Free Full Text

176. F Koh A, Molinaro A, Stahlman M, et al:: Microbially Produced Imidazole Propionate Impairs Insulin Signaling through mTORC1. Cell. 2018; 175(4): 947-961.e917.

PubMed Abstract | Publisher Full Text | Faculty Opinions Recommendation

177. Lee SH, Park Y, Yoon SK, et al:: Osmotic stress inhibits proteasome by p38 MAPK-dependent phosphorylation. J Biol Chem. 2010; 285(53): 41280-41289. PubMed Abstract | Publisher Full Text | Free Full Text

178. F Khurana A, Nakayama K, Williams S, et al:: Regulation of the ring finger E3 igase Siah2 by p38 MAPK. J Biol Chem. 2006; 281(46): 35316-35326. PubMed Abstract | Publisher Full Text | Free Full Text | Faculty Opinions Recommendation

179. Lalaoui N, Hanggi K, Brumatti G, et al:: Targeting p38 or MK2 Enhances the Anti-Leukemic Activity of Smac-Mimetics. Cancer Cell. 2016; 30(3): 499-500. PubMed Abstract | Publisher Full Text

180. F Jaco I, Annibaldi A, Lalaoui N, et al:: MK2 Phosphorylates RIPK1 to Prevent TNF-Induced Cell Death. Mol Cell. 2017; 66(5): 698-710.e5 PubMed Abstract | Publisher Full Text | Free Full Text | Faculty Opinions Recommendation

181. Dondelinger $\mathrm{Y}$, Delanghe T, Rojas-Rivera D, et al:: MK2 phosphorylation of RIPK1 regulates TNF-mediated cell death. Nat Cell Biol. 2017; 19(10): 1237-1247. PubMled Abstract | Publisher Full Text

182. Menon MB, Gropengiesser J, Fischer J, et al:: p38 MAPK/MK2-dependent phosphorylation controls cytotoxic RIPK1 signalling in inflammation and infection. Nat Cell Biol. 2017; 19(10): 1248-1259. PubMed Abstract | Publisher Full Text

183. Silke J, Rickard JA, Gerlic M: The diverse role of RIP kinases in necroptosis and inflammation. Nat Immunol. 2015; 16(7): 689-697. PubMed Abstract | Publisher Full Text

184. Dillon CP, Tummers $\mathrm{B}$, Baran $\mathrm{K}$, et al.: Developmental checkpoints guarded by regulated necrosis. Cell Mol Life Sci. 2016; 73(11-12): 2125-2136. PubMed Abstract | Publisher Full Text

185. del Barco Barrantes I, Coya JM, Maina F, et al:: Genetic analysis of specific and redundant roles for p38alpha and p38beta MAPKs during mouse development. Proc Natl Acad Sci U S A. 2011; 108(31): 12764-12769. PubMed Abstract | Publisher Full Text | Free Full Tex

186. Kang YJ, Chen J, Otsuka M, et al.: Macrophage deletion of p38alpha partially impairs lipopolysaccharide-induced cellular activation. J Immunol. 2008; 180(7): 5075-5082

PubMed Abstract | Publisher Full Text

187. Tiedje $\mathrm{C}$, Holtmann $\mathrm{H}$, Gaestel $\mathrm{M}$ : The role of mammalian MAPK signaling in regulation of cytokine mRNA stability and translation. J Interferon Cytokine Res. 2014; 34(4): 220-232. PubMed Abstract | Publisher Full Text

188. $\mathrm{Xu} \mathrm{Z,} \mathrm{Yoshida} \mathrm{T,} \mathrm{Wu} \mathrm{L,} \mathrm{et} \mathrm{al::} \mathrm{Transcription} \mathrm{factor} \mathrm{MEF2C} \mathrm{suppresses}$ endothelial cell inflammation via regulation of NF-kappaB and KLF2. J Cell Physiol. 2015; 230(6): 1310-1320. PubMed Abstract | Publisher Full Text | Free Full Text

189. Ronkina N, Menon MB, Schwermann J, et al.: Stress induced gene expression: a direct role for MAPKAP kinases in transcriptional activation of immediate early genes. Nucleic Acids Res. 2011; 39(7): 2503-2518. PubMed Abstract | Publisher Full Text | Free Full Text

190. F Ronkina N, Shushakova N, Tiedje C, et al:: The Role of TTP Phosphorylation in the Regulation of Inflammatory Cytokine Production by MK2/3. J Immunol. 2019; 203(8): 2291-2300.

PubMed Abstract | Publisher Full Text | Faculty Opinions Recommendation

191. Guan Z, Buckman SY, Pentland AP, et al.: Induction of cyclooxygenase-2 by the activated MEKK1 --> SEK1/MKK4 --> p38 mitogen-activated protein kinase pathway. J Biol Chem. 1998; 273(21): 12901-8. PubMed Abstract | Publisher Full Text

192. Badger AM, Cook MN, Lark MW, et al:: SB 203580 inhibits p38 mitogen-activated protein kinase, nitric oxide production, and inducible nitric oxide synthase in bovine cartilage-derived chondrocytes. J Immunol. 1998; 161(1): 467-73. PubMed Abstract

193. Da Silva J, Pierrat B, Mary JL, et al.: Blockade of p38 mitogen-activated protein kinase pathway inhibits inducible nitric-oxide synthase expression in mouse astrocytes. J Biol Chem. 1997; 272(45): 28373-80. PubMed Abstract | Publisher Full Text

194. Wiehler S, Cuvelier SL, Chakrabarti S, et al:: p38 MAP kinase regulates rapid matrix metalloproteinase-9 release from eosinophils. Biochem Biophys Res Commun. 2004; 315(2): 463-70 PubMed Abstract | Publisher Full Text

195. Zhou Y, Wu J, Liu C, et al.: p38alpha has an important role in antigen crosspresentation by dendritic cells. Cell Mol Immunol. 2018; 15(3): 246-259. PubMed Abstract | Publisher Full Text | Free Full Text

196. Craxton A, Shu G, Graves JD, et al:: $\mathbf{p 3 8}$ MAPK is required for CD40-induced gene expression and proliferation in B lymphocytes. J Immunol. 1998; 161(7): 3225-36. PubMed Abstract

197. Khiem D, Cyster JG, Schwarz JJ, et al:: A p38 MAPK-MEF2C pathway regulates 
B-cell proliferation. Proc Natl Acad Sci U S A. 2008; 105(44): 17067-72. PubMed Abstract | Publisher Full Text | Free Full Text

198. Wilker PR, Kohyama M, Sandau MM, et al.: Transcription factor Mef2c is required for $B$ cell proliferation and survival after antigen receptor stimulation. Nat Immunol. 2008; 9(6): 603-12.

PubMed Abstract | Publisher Full Text | Free Full Text

199. Zhang X, Fan L, Wu J, et al.: Macrophage p38 $\alpha$ promotes nutritiona steatohepatitis through M1 polarization. J Hepatol. 2019; 71(1): 163-174. PubMed Abstract | Publisher Full Text

200. F Otsuka M, Kang YJ, Ren J, et al.: Distinct effects of p38alpha deletion in myeloid lineage and gut epithelia in mouse models of inflammatory bowel disease. Gastroenterology. 2010; 138(4): 1255-65.1265.e1-9. PubMed Abstract | Publisher Full Text | Free Full Text Faculty Opinions Recommendation

201. Liang L, Li F, Bao A, et al:: Activation of p38 mitogen-activated protein kinase in ovalbumin and ozone-induced mouse model of asthma. Respirology. 2013; 18 Suppl 3: 20-29.

PubMed Abstract | Publisher Full Text

202. Gonzalez-Teran B, Matesanz N, Nikolic I, et al.: p38 $\gamma$ and p38 Reprogram Liver Metabolism by Modulating Neutrophil Infiltration. EMBO J. 2016; 35(5): 536-552. PubMed Abstract | Publisher Full Text | Free Full Text

203. Gonzalez-Teran B, Cortes JR, Manieri E, et al:: Eukaryotic Elongation Factor Controls TNF- $\alpha$ Translation in LPS-induced Hepatitis. J Clin Invest. 2013; 123(1): 164-178.

PubMed Abstract | Publisher Full Text | Free Full Text

204. Ittner A, Block $\mathrm{H}$, Reichel CA, et al.: Regulation of PTEN Activity by p38ס-PKD1 Signaling in Neutrophils Confers Inflammatory Responses in the Lung. $J$ Exp Med. 2012; 209(12): 2229-2246.

PubMed Abstract | Publisher Full Text | Free Full Text

205. Genovese MC: Inhibition of p38: has the fat lady sung? Arthritis Rheum. 2009; 60(12): 317-320.

PubMed Abstract | Publisher Full Text

206. Takenaka K, Moriguchi T, Nishida E: Activation of the protein kinase p38 in the spindle assembly checkpoint and mitotic arrest. Science. 1998; 280(5363): 599-602.

PubMed Abstract | Publisher Full Text

207. Molnar A, Theodoras AM, Zon LI, et al.: Cdc42Hs, but not Rac1, inhibits serumstimulated cell cycle progression at $\mathrm{G}_{1} / \mathrm{S}$ through a mechanism requiring p38/RK. J Biol Chem. 1997; 272(20): 13229-13235. PubMed Abstract | Publisher Full Text

208. Wang X, McGowan CH, Zhao M, et al.: Involvement of the MKK6-p38gamma cascade in gamma-radiation-induced cell cycle arrest. Mol Cell Biol. 2000; 20(13): 4543-4552.

PubMed Abstract | Publisher Full Text | Free Full Text

209. F Gubern $\mathrm{A}$, Joaquin $\mathrm{M}$, Marquès $\mathrm{M}$, et al:: The $\mathrm{N}$-Terminal Phosphorylation of RB by $\mathrm{P} 38$ Bypasses Its Inactivation by CDKs and Prevents Proliferation in Cancer Cells. Mol Cell. 2016; 64(1): 25-36.

PubMed Abstract | Publisher Full Text | Faculty Opinions Recommendation

210. Yee AS, Paulson EK, McDevitt MA, et al.: The HBP1 transcriptional repressor and the P38 MAP kinase: unlikely partners in G1 regulation and tumor suppression. Gene. 2004; 336(1): 1-13. PubMed Abstract | Publisher Full Text

211. Kumari G, Ulrich T, Gaubatz S: A role for p38 in transcriptional elongation of p21 ${ }^{\mathrm{CIP} 1}$ in response to Aurora B inhibition. Cell Cycle. 2013; 12(13): 2051-2060. PubMed Abstract | Publisher Full Text | Free Full Text

212. Saha K, Adhikary G, Kanade SR, et al.: p38 regulates $p 53$ to control p21 cip expression in human epidermal keratinocytes. J Biol Chem. 2014; 289(16): 11443-11453.

PubMed Abstract | Publisher Full Text | Free Full Text

213. Niu Z, Mu H, Zhu H, et al:: p38 MAPK pathway is essential for self-renewal of mouse male germline stem cells (mGSCs). Cell Prolif. 2017; 50(1): e12314. PubMed Abstract | Publisher Full Text | Free Full Text

214. F Liu S, Ginzberg MB, Patel N, et al:: Size uniformity of animal cells is actively maintained by a 338 MAPK-dependent regulation of G1-length. eLife. 2018; 7 : e26947.

PubMed Abstract | Publisher Full Text | Free Full Text |

Faculty Opinions Recommendation

215. Morooka T, Nishida E: Requirement of p38 mitogen-activated protein kinase fo neuronal differentiation in PC12 cells. J Biol Chem. 1998; 273(38): 24285-24288. PubMed Abstract | Publisher Full Text

216. Li Y, Jiang B, Ensign WY, et al.: Myogenic differentiation requires signalling through both phosphatidylinositol 3-kinase and p38 MAP kinase. Cell Signal. 2000; 12(110-12): 751-757. PubMed Abstract | Publisher Full Tex

217. Cao W, Medvedev AV, Daniel KW, et al.: $\beta$-Adrenergic activation of p38 MAP kinase in adipocytes: cAMP induction of the uncoupling protein 1 (UCP1) gene requires p38 MAP kinase J Biol Chem. 2001; 276(29): 27077-27082. PubMed Abstract | Publisher Full Text

218. Cao W, Daniel KW, Robidoux J, et al:: p38 mitogen-activated protein kinase is the central regulator of cyclic AMP-dependent transcription of the brown fat uncoupling protein 1 gene. Mol Cell Biol. 2004; 24(7): 3057-3067. PubMed Abstract | Publisher Full Text | Free Full Text
219. F Matesanz N, Nikolic I, Leiva M, et al.: p38 $\alpha$ blocks brown adipose tissue thermogenesis through 388 inhibition. PLOS Biol. 2018; 16(7): e2004455. PubMed Abstract | Publisher Full Text | Free Full Text | Faculty Opinions Recommendation

220. F Zhang S, Cao H, Li Y, et al:: Metabolic benefits of inhibition of p38 $\alpha$ in white adipose tissue in obesity. PLOS Biol. 2018; 16(5): e2004225. PubMed Abstract | Publisher Full Text | Free Full Text | Faculty Opinions Recommendation

221. Jing $Y$, Liu $W, \mathrm{Cao} H$, et al.: Hepatic p38a regulates gluconeogenesis by suppressing AMPK. J Hepatol. 2015; 62(6): 1319-1327. PubMed Abstract | Publisher Full Text

222. F Lanna A, Henson SM, Escors D, et al.: The kinase p38 activated by the metabolic regulator AMPK and scaffold TAB1 drives the senescence of human T cells. Nat Immunol. 2014; 15(10): 965-972. PubMed Abstract | Publisher Full Text | Free Full Text | Faculty Opinions Recommendation

223. F Wang W, Chen JX, Liao R, et al:: Sequential activation of the MEKextracellular signal-regulated kinase and MKK3/6-p38 mitogen-activated protein kinase pathways mediates oncogenic ras-induced premature senescence. Mol Cell Biol. 2002; 22(10): 3389-3403. PubMed Abstract | Publisher Full Text | Free Full Text | Faculty Opinions Recommendation

224. F Haq R, Brenton JD, Takahashi M, et al:: Constitutive p38HOG mitogen activated protein kinase activation induces permanent cell cycle arrest and senescence. Cancer Res. 2002; 62(17): 5076-5082. PubMed Abstract | Faculty Opinions Recommendation

225. Tivey HS, Brook AJ, Rokicki MJ, et al:: p38 $^{\text {MAPK }}$ stress signalling in replicative senescence in fibroblasts from progeroid and genomic instability syndromes. Biogerontology. 2013; 14(1): 47-62.

PubMed Abstract | Publisher Full Text | Free Full Text

226. Naka K, Tachibana A, Ikeda $\mathrm{K}$, et al:: Stress-induced premature senescence in hTERT-expressing ataxia telangiectasia fibroblasts. J Biol Chem. 2004; 279(3) 2030-2037.

PubMed Abstract | Publisher Full Text

227. Dimozi A, Mavrogonatou E, Sklirou A, et al:: Oxidative stress inhibits the proliferation, induces premature senescence and promotes a catabolic phenotype in human nucleus pulposus intervertebral disc cells. Eur Cell Mater. 2015; 30: 89-102.

PubMed Abstract | Publisher Full Text

228. Borodkina AV, Shatrova AN, Nikolsky NN, et al.: Role of P38 Map-Kinase in the Stress-Induced Senescence Progression of Human Endometrium-Derived Mesenchymal Stem Cells. Tsitologiia. 2016; 58(6): 429-435. PubMed Abstract

229. Harada G, Neng Q, Fujiki T, et al:: Molecular mechanisms for the p38-induced cellular senescence in normal human fibroblast. J Biochem. 2014; 156(5): 283-290

PubMed Abstract | Publisher Full Text

230. Hongo A, Okumura N, Nakahara M, et al.: The Effect of a p38 Mitogen-Activated Protein Kinase Inhibitor on Cellular Senescence of Cultivated Human Corneal Endothelial Cells. Invest Ophthalmol Vis Sci. 2017; 58(9): 3325-3334. PubMed Abstract | Publisher Full Text

231. Han J, Sun P: The pathways to tumor suppression via route p38. Trends Biochem Sci. 2007; 32(8): 364-371. PubMed Abstract | Publisher Full Text

232. F Freund $\mathrm{A}$, Patil $\mathrm{CK}$, Campisi $\mathrm{J}$ : p38MAPK is a novel DNA damage responseindependent regulator of the senescence-associated secretory phenotype. EMBO J. 2011; 30(8): 1536-1548.

PubMed Abstract | Publisher Full Text | Free Full Text | Faculty Opinions Recommendation

233. Zhang $B, F u D, X u Q$, et al:: The senescence-associated secretory phenotype is potentiated by feedforward regulatory mechanisms involving Zscan 4 and TAK1. Nat Commun. 2018; 9(1): 1723. PubMed Abstract | Publisher Full Text | Free Full Text

234. Alimbetov D, Davis T, Brook AJ, et al: Suppression of the senescence-associated secretory phenotype (SASP) in human fibroblasts using small molecule inhibitors of p38 MAP kinase and MK2. Biogerontology. 2016; 17(2): 305-315. PubMed Abstract | Publisher Full Text | Free Full Text

235. Coppe JP, Desprez PY, Krtolica A, et al.: The senescence-associated secretory phenotype: the dark side of tumor suppression. Annu Rev Pathol 2010: 5: 99-118. PubMed Abstract | Publisher Full Text | Free Full Text

236. Xia Z, Dickens M, Raingeaud J, et al.: Opposing effects of ERK and JNK-p38 MAP kinases on apoptosis. Science. 1995; 270(5240): 1326-1331. PubMed Abstract | Publisher Full Text

237. Kummer JL, Rao PK, Heidenreich KA: Apoptosis induced by withdrawal of trophic factors is mediated by $\mathrm{p} 38$ mitogen-activated protein kinase. $J$ BiO Chem. 1997; 272(33): 20490-20494.

PubMed Abstract | Publisher Full Text

238. Cahill MA, Peter ME, Kischkel FC, et al.: CD95 (APO-1/Fas) induces activation of SAP kinases downstream of ICE-like proteases. Oncogene. 1996; 13(10): 2087-2096.

PubMed Abstract

239. Huang S, Jiang Y, Li Z, et al.: Apoptosis signaling pathway in T cells is composed 
of ICE/Ced-3 family proteases and MAP kinase kinase 6b. Immunity. 1997; 6(6): 739-749

PubMed Abstract | Publisher Full Text

240. Cardone MH, Salvesen GS, Widmann C, et al:: The regulation of anoikis: MEKK1 activation requires cleavage by caspases. Cell. 1997; 90(2): 315-323. PubMed Abstract | Publisher Full Text

241. Tan W, Yu HG, Luo HS: Inhibition of the p38 MAPK pathway sensitizes human gastric cells to doxorubicin treatment in vitro and in vivo. Mol Med Rep. 2014; 10(6): 3275-3281.

PubMed Abstract | Publisher Full Text

242. Slawinska-Brych A, Zdzisinska B, Mizerska-Dudka M, et al:: Induction of apoptosis in multiple myeloma cells by a statin-thalidomide combination can be enhanced by $\mathrm{p} 38$ MAPK inhibition. Leuk Res. 2013; 37(5): 586-594. PubMed Abstract | Publisher Full Text

243. Dolgin E: The most popular genes in the human genome. Nature. 2017; 551(7681): 427-431.

PubMed Abstract | Publisher Full Text

244. F Alam MS, Gaida MM, Bergmann F, et al: Selective inhibition of the p38 alternative activation pathway in infiltrating $T$ cells inhibits pancreatic cancer progression. Nat Med. 2015; 21(11): 1337-1343. PubMed Abstract | Publisher Full Text | Free Full Text | Faculty Opinions Recommendation

245. Luk ST, Ng KY, Zhou L, et al.: Deficiency in Embryonic Stem Cell Marker Reduced Expression 1 Activates Mitogen-Activated Protein Kinase Kinase 6-Dependent p38 Mitogen-Activated Protein Kinase Signaling to Drive Hepatocarcinogenesis. Hepatology. 2019. PubMed Abstract | Publisher Full Text

246. Salome M, Magee A, Yalla K, et al:: A Trib2-p38 axis controls myeloid leukaemia cell cycle and stress response signalling. Cell Death Dis. 2018; 9(5): 443. PubMed Abstract | Publisher Full Text | Free Full Text

247. F Gibbs KL, Kalmar B, Rhymes ER, et al:: Inhibiting p38 MAPK alpha rescues axonal retrograde transport defects in a mouse model of ALS. Cell Death Dis. 2018; 9(6): 596.

PubMed Abstract | Publisher Full Text | Free Full Text | Faculty Opinions Recommendation

248. F Fang C, Wu B, Le NTT, et al.: Prions activate a p38 MAPK synaptotoxic signaling pathway. PLoS Pathog. 2018; 14(9): e1007283. PubMed Abstract | Publisher Full Text | Free Full Text | Faculty Opinions Recommendation

249. F Obergasteiger J, Frapporti G, Pramstaller PP, et al.: A new hypothesis for Parkinson's disease pathogenesis: GTPase-p38 MAPK signaling and autophagy as convergence points of etiology and genomics. Mo Neurodegener. 2018; 13(1): 40

PubMed Abstract | Publisher Full Text | Free Full Text | Faculty Opinions Recommendation
250. F Wang PY, Hsu PI, Wu DC, et al.: SUMOs Mediate the Nuclear Transfer of p38 and p-p38 during Helicobacter Pylori Infection. Int J Mol Sci. 2018; 19(9): 2482. PubMed Abstract | Publisher Full Text | Free Full Text | Faculty Opinions Recommendation

251. F Zhang F, Zhao Q, Tian J, et al:: Effective Pro-Inflammatory Induced Activity of GALT, a Conserved Antigen in A. Pleuropneumoniae, Improves the Cytokines Secretion of Macrophage via p38, ERK1/2 and JNK MAPKs Signal Pathway. Front Cell Infect Microbiol. 2018; 8: 337.

PubMed Abstract | Publisher Full Text | Free Full Text | Faculty Opinions Recommendation

252. Zhu J, Yu W, Liu B, et al:: Escin induces caspase-dependent apoptosis and autophagy through the ROS/p38 MAPK signalling pathway in human osteosarcoma cells in vitro and in vivo. Cell Death Dis. 2017; 8(10): e3113. PubMed Abstract | Publisher Full Text | Free Full Text

253. Fan $\mathrm{H}, \mathrm{Gao} \mathrm{Z}$, Ji K, et al.: The in vitro and in vivo anti-inflammatory effect of osthole, the major natural coumarin from Cnidium monnieri (L.) Cuss, via the blocking of the activation of the NF-kappaB and MAPK/p38 pathways. Phytomedicine. 2019; 58: 152864. PubMed Abstract | Publisher Full Text

254. Li Y, Xu B, Xu M, et al.: 6-Gingerol protects intestinal barrier from ischemia/ reperfusion-induced damage via inhibition of p38 MAPK to NF-kappaB signalling. Pharmacol Res. 2017; 119: 137-148. PubMed Abstract | Publisher Full Text

255. Zhang $X$, Wang $X$, Wu T, et al:: Isoliensinine induces apoptosis in triple-negative human breast cancer cells through ROS generation and p38 MAPK/JNK activation. Sci Rep. 2015; 5: 12579. PubMed Abstract | Publisher Full Text | Free Full Text

256. Bachegowda L, Morrone K, Winski SL, et al.: Pexmetinib: A Novel Dual Inhibitor of Tie2 and p38 MAPK with Efficacy in Preclinical Models of Myelodysplastic Syndromes and Acute Myeloid Leukemia. Cancer Res. 2016; 76(16): 4841-4849. PubMed Abstract | Publisher Full Text | Free Full Text

257. O'Donoghue ML, Glaser R, Aylward PE, et al.: Rationale and design of the LosmApimod To Inhibit p38 MAP kinase as a TherapeUtic target and moDify outcomes after an acute coronary syndromE trial. Am Heart J. 2015; 169(5): $622-630.66$.

PubMed Abstract | Publisher Full Text

258. Emami H, Vucic E, Subramanian S, et al:: The effect of BMS-582949, a P38 mitogen-activated protein kinase (P38 MAPK) inhibitor on arterial inflammation: a multicenter FDG-PET trial. Atherosclerosis. 2015; 240(2): 490-496. PubMed Abstract | Publisher Full Text

259. Moran N: p38 kinase inhibitor approved for idiopathic pulmonary fibrosis. Nat Biotechnol. 2011; 29(4): 301

PubMed Abstract | Publisher Full Text 


\section{Open Peer Review}

\section{Current Peer Review Status:}

\section{Editorial Note on the Review Process}

Faculty Reviews are review articles written by the prestigious Members of Faculty Opinions. The articles are commissioned and peer reviewed before publication to ensure that the final, published version is comprehensive and accessible. The reviewers who approved the final version are listed with their names and affiliations.

\section{The reviewers who approved this article are:}

\section{Version 1}

\section{Guadalupe Sabio}

Centro Nacional de Investigaciones Cardiovasculares (CNIC), Madrid, Spain

Competing Interests: No competing interests were disclosed.

\section{Jonathan D. Ashwell} Laboratory of Immune Cell Biology, Center for Cancer Research, National Cancer Institute, National Institutes of Health, Bethesda, MD, 20892, USA

Competing Interests: No competing interests were disclosed.

The benefits of publishing with F1000Research:

- Your article is published within days, with no editorial bias

- You can publish traditional articles, null/negative results, case reports, data notes and more

- The peer review process is transparent and collaborative

- Your article is indexed in PubMed after passing peer review

- Dedicated customer support at every stage

For pre-submission enquiries, contact research@f1000.com 